\title{
The Role of the Home Environment in Dementia Care: Systematic Review of Qualitative Research
}

\author{
Dia Soilemezi, Amy Drahota, John Crossland, Rebecca Stores
}

\begin{abstract}
Background: The domestic home is the preferred site for care provision for people with dementia and their families, therefore creating a dementia and caring friendly home environment is crucial. This systematic review synthesised qualitative studies to explore the role of the home environment and identify potential barriers and facilitators in home dementia care and support to inform future practice and research.
\end{abstract}

Methods: A systematic search in 12 databases identified international qualitative literature on perceptions and experiences of community-dwelling people with dementia, family and formal carers regarding the role of the home environment and ways to tackle daily challenges.

Results: Forty qualitative studies were included and analysed using thematic synthesis. The main three themes were: "home as a paradox", "there is no magic formula", and "adapting the physical space, objects and behaviour". Findings indicate that home is an important setting and is likely to change significantly responding to the changing nature of dementia. Themes were later validated by family carers of people with dementia.

Conclusions: The home environment is an important setting for care and needs to remain flexible to accommodate changes and challenges. Family carers and people with dementia implement, and often improvise, various environmental strategies. Continuous and tailormade support at home is required.

\section{Keywords}

Dementia, home environment, systematic review, qualitative, thematic synthesis 


\section{Introduction}

The rapid growth of the elderly population has increased the number of people who are diagnosed with dementia, with over 46 million people globally living with dementia (Prince et al., 2015) and over 850,000 people in the UK (Alzheimer's Society, 2014). The financial cost for dementia care per year is estimated at around $£ 26$ billion with this number estimated to increase to $£ 50$ billion in the next 30 years, more than the costs for heart disease, stroke and cancer care put together (Alzheimer's Society, 2014; Luengo-Fernandez, Leal, \& Gray, 2010).

The majority of people with dementia are cared for in their own home, making informal caregiving a significant proportion of dementia care provision (WHO, 2012). Research shows that the role of the family carer is crucial to the survival and quality of life of the person with dementia (Banerjee et al., 2003; Cooke et al., 2001). It is perhaps not surprising that carers are found to have significantly decreased quality of life compared to the general older population (Argimon, Limon, Vila, \& Cabezas, 2004). One of the most challenging aspects for carers is dealing with the neuropsychiatric symptoms of dementia, such as agitation, wandering, restlessness, and apathy, and several reviews have examined non-pharmacological interventions to support people with dementia and their carers (Brodaty, Green, \& Koschera, 2003; Cooke et al., 2001; Moniz Cook et al., 2012; Parker, Mills, \& Abbey, 2008; Pinquart \& Sorensen, 2006; Torti, Gwyther, Reed, Friedman, \& Schulman, 2004). Until a cure is found, it has been argued that examining the suitability of the home environment (e.g. size, layout) and manipulating the physical environment (e.g. adaptations) can play a significant role in the management of dementia and the quality of life of both the patient and carer (Garcia, Kartolo, \& Méthot-Curtis, 2012; Gitlin, Liebman, \& Winter, 2003; Robinson et al., 2006; van Hoof, Kort, van Waarde, \& Blom, 2010).

Researching the home environment and ageing in place has increasingly become the focus of dementia care and is crucial for a number of reasons. It is a consistent wish of older 
people to remain at home (van der Roest et al., 2007; WHO, 2012) as they feel attached to it; it is a central, meaningful and important place for them (Petersson, Lilja, \& Borell, 2012). Also, ageing in place means shifting the support from long-term care services (e.g. nursing or residential care), to home-based care (either family or professional) and thus optimising the physical domestic setting to compensate for one's disabilities is crucial. An enabling, safe and comfortable environment may reduce particular behavioural stressors, support the individual to use available competencies, and reduce carers' strain (Gitlin \& Corcoran, 1996; Unwin, Andrews, Andrews, \& Hanson, 2009). Ageing in place and home care is estimated to be less costly than providing accommodation in a long-term care facility (van der Roest et al., 2007), which apart from constituting the biggest cost to health system (WHO, 2012), can have detrimental effect on the person with dementia (Bradshaw, Playford, \& Riazi, 2012; Zarit, Gaugler, \& Jarrott, 1999). Therefore, living with dementia at home, and supporting this for as long as possible are important objectives for individuals, society and governments.

The person-environment fit (or environmental press) model is the pivotal framework in person-environment research (Kahana, Lovegreen, Kahana, \& Kahana, 2003; Lawton, 1990) that has been used in many intervention studies to explore the usefulness of environmental modifications (Wahl \& Weisman, 2003) and residential satisfaction (Kahana et al., 2003). Several reviews, including Cochrane reviews, have examined the effectiveness of different environments and/or environmental strategies in dementia care, such as lighting (Forbes, Blake, Thiessen, Peacock, \& Hawranik, 2014; Torrington \& Tregenza, 2007), special care units (Lai, Yeung, Mok, \& Chi, 2009), Snoezelen (Chung \& Lai, 2009), music (Vink, Bruinsma, \& Scholten, 2011), built environment (Soril et al., 2014), aromatherapy (Holt et al., 2009; Nguyen \& Paton, 2008), subjective barriers (Price, Hermans, \& Grimley Evans, 2009), or a variety of strategies (Day, Carreon, \& Stump, 2000; Gitlin et al., 2003). All these reviews focused mainly on residential care settings apart from one (Gitlin et al., 2003) that also 
included private homes. To our knowledge, there has not been any updated nor qualitative review that examined aspects of home environment together with environmental strategies.

However, a number of qualitative studies exploring the experiences and perceptions of the role of home environment and helpful (or not) interventions have been undertaken. Qualitative studies are useful in exploring people's experiences, acceptance and satisfaction with interventions, especially in domestic settings which is a largely ignored territory (van Hoof \& Kort, 2009). Previous qualitative syntheses have been conducted to explore various aspects and impact of dementia: living with early stage dementia (Steeman, Casterle, Godderis, \& Grypdonck, 2006), the dementia diagnosis and treatment (Bunn et al., 2012), the impact of dementia on marriage (Evans \& Lee, 2014), psychosocial interventions for dementia (Dugmore, Orrell, \& Spector, 2015), the needs of carers during transition from home to institutional care (Afram, Verbeek, Bleijlevens, \& Hamers, 2014), and the quality of life in care homes (Bradshaw et al., 2012). To date, there has been no systematic review exploring environmental features and strategies that are perceived as helpful in home dementia care and support (either formal or informal), which justifies the need for the current review.

The aim of this review is to explore and synthesise qualitative evidence on the experiences of people with dementia and their carers of their home environment, and environmental strategies perceived as helpful and acceptable. The research question is 'What is the role of the home environment in dementia care?'. This review is intended to identify barriers and facilitators that impact in effective dementia care at home in order to inform people with dementia, their informal carers, health and social care professionals, as well as professionals working in environmental design. Equally, this review also aimed to provide some evidence-based guidance to policy makers and general public to better understand the lived experience, issues of independence and comfort for people with dementia and their 
family carers and thus highlight environmental considerations in dementia care and identify research gaps. Systematic reviews allow transferability, prevent unnecessary duplication of research, and are invaluable for busy practitioners as they combine results from many studies, provide up-to-date summarised evidence and disseminate them in an unbiased and rigorous manner (Dixon-Woods, Agarwal, Young, Jones, \& Sutton, 2004; Pope \& Mays, 2006). A protocol (Soilemezi, Drahota, Stores, \& Crossland, 2013) was published setting out all aspects of the review plan.

\section{Methods}

Inclusion criteria

We adopted the approaches by Drahota et al. (2012) and van Hoof \& Kort (2009) to refer to any internal aspects of the home surroundings that can be seen, touched, smelt, or heard, and interior elements. This included: (a) the built environment and architectural elements (walls, flooring, windows, size, lay-out), (b) ambient and interior elements (thermal, visual, olfactory, tactile, acoustic aspects and indoor air), and (c) technologies, equipment and devices. In addition, we included the 'lived' experience of home, as a personal dimension of home experience. Qualitative studies that looked at any aspect of these and/or the manipulation or strategies involving these aspects, were relevant for inclusion.

Publications were screened as to whether they met the following criteria:

- $\quad$ Primary qualitative studies, or qualitative studies that were part of a mixed methods project, from any geographical location published from 1970 onwards.

- Studies published in English, German and Greek were included as members of the research team were fluent. 
- $\quad$ The study population had to include either people with dementia (of any type, stage and age who live at home), informal carers (e.g. family, friends, neighbours) or healthcare professionals who work and support people with dementia and their carers in the community. - The study had to examine either experiences, attitudes and/or beliefs around the impact of the home environment, acceptability and preferences of environmental components, barriers and facilitators to managing dementia at home and/or perceptions of what is helpful (or not) and why.

- $\quad$ Any type of private dwelling (house, flat, apartment, maisonette, bungalow, cottage) was included. We also included supported accommodation (e.g. retirement housing), as it is a self-contained accommodation that allows people to live independently with available help if needed.

- Studies that used any qualitative methods (including grounded theory, ethnography, narrative analysis, and phenomenology) were included.

Studies were excluded if the sample was mixed (e.g. a mixture of people with dementia and people with other long-term conditions) and the findings were not reported separately. However, if the study sample was mixed and the majority of the population under investigation (person with dementia, carers and/or professionals) met our inclusion criteria, then it was included. The same rule applied with the setting: if participants came from mixed residences, and data were separately reported for participants living at home or they formed the majority of sample, then studies were included. In addition, studies that solely looked at the design or/and evaluation of a specific device (e.g. prototype development of an assistive or smart technology) without reporting the participants' views on the role of their home environment, were excluded. Studies on experiences of using everyday technologies and other aspects of the home environment were included. 


\section{Search strategy}

Our search strategy was intentionally broad and inclusive to ensure retrieval of all relevant papers and improve coverage of the review (Saini \& Shlonsky, 2012) knowing that qualitative studies can be particularly challenging to identify and retrieve (Barroso et al., 2003; Pope \& Mays, 2006; Wong, Wilczynski, \& Haynes, 2004) and due to the complexity of the context of the home environment. An initial search was performed in MEDLINE and Cumulative Index to Nursing and Allied Health Literature (CINAHL) that indicated key terms and text words, after testing and exploding the main terms in order to achieve the best sensitivity (Wilczynski, Marks, \& Haynes, 2007). This exercise informed the second extensive search (May 2013) on 12 databases (from 1970-2013): MEDLINE, CINAHL, Art and Architecture Complete (AAC), SocIndex, PsycINFO, British Architectural Library Catalogue (BALC), Joanna Briggs Institute (JBI), Social Care Online, Social Sciences Citation Index (SSCI), Science Direct, Campbell Library and Center for International Rehabilitation Research Information and Exchange (CIRRIE). Five sets of search terms (Table 1) were used to capture the key research question components: people with dementia, carers, professionals, environmental terms and qualitative research. These were then combined using Boolean operators (OR/AND) to identify potentially eligible citations $(N=17,824)$. Searching of reference lists, grey literature (such as conference proceedings, theses, organisational reports) and key author searches were also conducted as suggested by previous research (Pope \& Mays, 2006; Saini \& Shlonsky, 2012). References from relevant published reviews were also searched. Duplicates were deleted and final results were saved on EndNote software (Figure 1). 


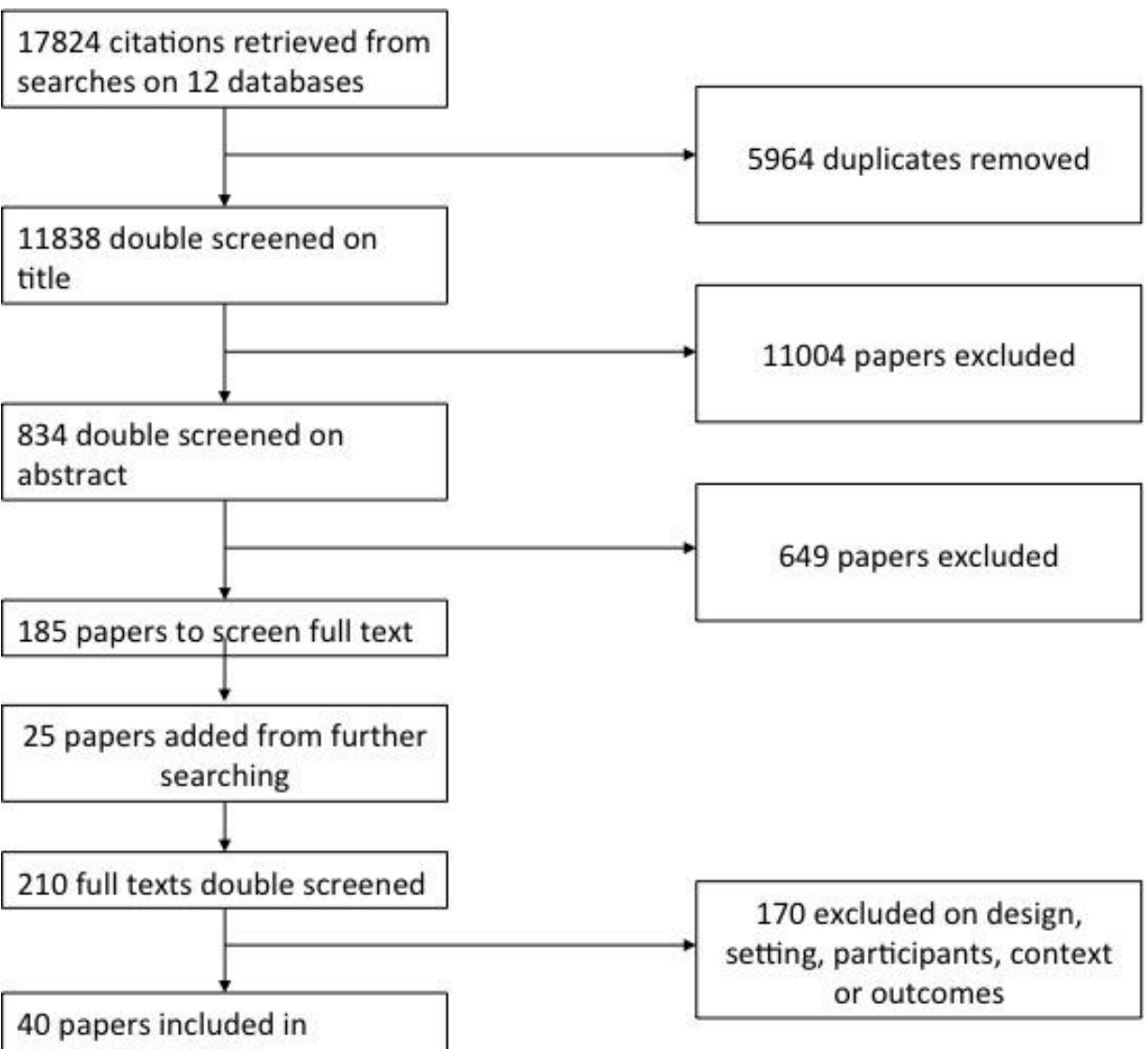

thematic synthesis

Figure 1. Flowchart of the Screening Process And Search Results

\section{Data screening}

Papers were double screened independently by the main author (DS) and a second member of the interdisciplinary research team (AD, RS, JC). Screening was done in three stages: initially on titles, then abstracts, and finally on full papers. A very broad-based screening approach was followed knowing that titles and abstracts may provide insufficient information to base our judgement on the relevance of the studies, as indicated by previous literature (Saini \& Shlonsky, 2012). This was decided to ensure we did not limit the exploration of our phenomena and inevitably omit relevant studies too early. Disagreements were resolved by consensus or by discussion with a third reviewer from the research team. 


\section{Data extraction}

The main author (DS) extracted data from all included publications, which included: type of study design, year when study was conducted, theoretical framework, study aims, methods, type and demographics of participants, setting, method of analysis of the primary data and outcomes (Table 2).

\section{Quality assessment}

The use of quality assessment tools, the judgement to include/exclude studies based on quality, and what criteria/threshold should be used, has been debated widely in the literature (Carroll \& Booth, 2015). The aim of our quality assessment was not to score studies on their design in order to exclude them but to assess their relevance in answering the review question, as suggested by previous research (Thomas \& Harden, 2008). We thus decided to include all studies regardless of the quality in order to ensure that the phenomenon of interest is fully captured and to add richness of our findings but without ignoring their strengths and/or weaknesses (Saini \& Shlonsky, 2012). The Critical Appraisal Skills Programme (CASP) checklist, which consists of ten questions, was used to evaluate the included papers methodologically (Table 3). CASP helped the assessors to become familiar with the strengths and limitations both within and also across studies and provide an indication of the robustness of the review. The main author (DS) evaluated all studies independently. The research supervision team checked a quarter of the studies $(n=10)$, discussed and resolved any disagreements. Afterwards, the main author (DS) also conducted a sensitivity analysis. This involved reanalysing the data without the studies considered to be of low quality (scoring $<8$ out of 10) to examine whether the final themes were affected significantly after removing those studies from the synthesis. 


\section{Data synthesis}

This synthesis aimed to identify barriers and facilitators and answer a predefined question. For this reason, thematic synthesis was used, as it is a useful method to produce concrete outcomes to inform policy and practitioners (Thomas \& Harden, 2008). Included papers were systematically reviewed, coded and analysed by the main author (DS). The rest of the reviewers met and discussed the initial codes/topics, helped to refine the final themes and validated the findings. The logic and understanding of final themes were further discussed and validated in a workshop with lay members (including carers of people with dementia), researchers and practitioners which provided additional validation to the review themes.

The analysis involved three stages. Firstly, each study was read repeatedly and relevant text was highlighted and coded in QSR International's NVivo 10 Software. Data included all the text labelled as 'results' or 'findings' and in few cases even the discussion section (Thomas and Harden, 2008). Secondly, the coded data were read again to identify any patterns, similarities and differences, while preserving the context of the original studies. The codes from the inductive analysis were revisited and grouped together into a hierarchical structure in several layers to produce descriptive themes and topics. When necessary, new codes were created to represent the meaning and association between codes, ensuring that the reviewer remained very close to the findings. Finally, the reviewer used the descriptive themes to 'go beyond' the original studies and answer the review questions (Thomas and Harden, 2008), which enabled the generation of final themes. When the themes and subthemes were finalised, the main author (DS) discussed them with the co-reviewers to refine and rename them. 


\section{Results \\ Description of included studies}

Overall, forty two papers reporting forty studies met all criteria and were included in the review (Table 4). They involved studies from nine countries: USA ( $n=12)$, UK $(n=11)$, Sweden ( $n=7)$, Turkey $(n=1)$, Australia $(n=1)$, Canada $(n=4)$, Netherlands $(n=2)$, Colombia ( $n=1)$, and Hong Kong ( $n=1)$. Studies were published between 1995 and 2013. All papers were research articles apart from one (Dickson, 2012) that was a doctoral thesis. The studies included 1,145 participants, the majority of them informal carers $(n=653)$ across 33 studies, followed by people with dementia ( $n=372)$ across 18 studies, and professionals $(n=120)$ across eight studies. From the thirty-three studies that reported participants' characteristics, the people with dementia were aged from 57 to 96 and informal carers were aged from 23 to 91. From the eight studies that included professionals, only a single study provided information on their age, ranging from 34 to 51. Ethnicity, stage of dementia, type of carer, age of the participants, year study was conducted and type of analysis were frequently not reported. The majority of studies used interviews $(n=32)$ as the main method of data collection. The rest used focus groups $(n=6)$, video recording $(n=1)$ and open-ended questionnaire $(n=1)$ as the main method.

Studies varied in analytical methods described, ranging from constant comparison $(n=$ $10)$, thematic $(n=5)$, content $(n=4)$, grounded theory $(n=4)$, empirical phenomenological psychological $(n=2)$, framework analysis $(n=1)$, theoretical framework $(n=1)$, van Manen's method $(n=1)$, table narrative $(n=1)$, Dilorio's method $(n=1)$, Colaizzi's method $(n=1)$, and others were not clearly reported $(n=9)$. Six studies involved only people with dementia, seventeen only informal carers, one involved only paid carers, ten studies involved both the people with dementia and their informal carers, three involved family carers together with paid carers, one with people with dementia and healthcare professionals, and two studies involved people with dementia, family carers and professionals. Whilst all studies 
contributed data relevant to this review's question, for some studies this was not their key focus (e.g. the environment may only have formed part of a wider focus of the primary study). The majority of the studies $(n=17)$ reported general environmental strategies, some studies specifically reported on use of technologies and equipment $(n=10)$ and music $(n=2)$ and the rest of the studies $(n=11)$ reported participants' perceptions and general experiences of living at home with dementia.

\section{Quality of included studies}

In terms of quality, three studies provided information to answer all 10 criteria on the CASP checklist and hence were considered of good quality; the majority of studies $(n=37)$ lacked or missed some methodological information (Table 5). The relationship between the researcher and participants was not reported in most studies $(n=35)$, followed by ethical considerations $(n=13)$ and insufficient description of the process of analysis $(n=15)$. There were six studies (Dodds, 1994; Dröes, 2006; Forbat, 2003; Nochajski, 2013; Olsen, 1996; van Hoof, 2009) that did not address all three above-mentioned elements and could be considered of low quality. The sensitivity analysis showed that their contribution was minor to formation of the three main themes, as the main themes did not change after removing these studies. However, when the subthemes were examined, it was noted that one study (Olsen, 1996) made a considerable contribution to the formation of a subtheme ('layout and accessibility'), and part of the second subtheme (2.2 'useful home components').

\section{Thematic synthesis}

The thematic synthesis enabled the generation of three final themes and a number of subthemes (Table 6). Some themes and their subthemes derived from a number of studies with few data to report and other derived from a substantial number of data reported in the 
studies included. Direct quotations from included studies were taken to represent the key themes and are presented in Table 7.

1. Home as a paradox. This theme reports the experiences of living at home for people with dementia and their family carers and ways their home and hence their experience of it has changed over time. It presents a number of examples of tensions that have impacted on the meaning and experience of home.

1.1 Home, sweet home. Home is a very important place with profound significance for people with dementia (Aminzadeh, 2010; Sixsmith, 2007). Home is associated with positive feelings for people with dementia and is the centre of their lives (de Witt, 2009). Home is a (a) centre of socialisation, (b) locus of autonomy and control, (c) locus of familiarity and constancy, (d) place of retreat, (e) repository of memories of life history, (f) site of the expression of personal interests and values, $(\mathrm{g})$ site of the expression of functional competence and engagement in meaningful activities (Aminzadeh, 2010). Cherished personal possessions reveal a strong attachment to people's home, displaying their interests, values and life achievements (Aminzadeh, 2010). Leaving their home was perceived by people with dementia as a death sentence (de Witt, 2009).

1.2 Home experience disrupted. Dementia changed the way people with dementia and co-resident carers experienced their home and provoked a series of tensions and discontinuity (Kinney, 2003). Home became a paradox due to the disruptions caused by the adaptations and the psychological tensions, as home was experienced not only as a place of strong attachment but also a burden (Aminzadeh, 2010) and carers' needs were weighed against their relatives' needs (Olsson, 2011). Studies pointed to the disruption of the sense of homeliness (Aminzadeh, 2010); home was changing its homely character and gaining more of an institutional look, gradually becoming a place of negative experiences and a medicalised space, for example, bedrooms resembling a hospital room (de la Cuesta, 2005). From the 
carers' perspective, the findings highlighted the lack of privacy and personal space (physical and emotional) as a contributing factor to the home experience being disrupted (Dröes, 2006; Spring, 2009; Olsen, 1996), smells and disposal of waste as distressing and embarrassing (Drennan, 2011), and feeling like a prisoner at home (Taşc1, 2012). Homes were transformed into hybrid places, 'almost-homes', where family life is combined with clinical care and identities were merged (de la Cuesta, 2005).

1.3 Home tensions. There were three main tensions experienced at home that carers and/or people with dementia faced and tried to overcome:

\subsubsection{Tension between safety versus comfort: Maintaining safety was paramount} (Kinney, 2003; Olsen, 1996; Richter, 1995) but also was the reason for constant supervision and why adaptations were made (Kinney, 2003; Nochajski, 2013), including to avoid falls and accidents (Dickson, 2012; Kinney, 2003; Olsen, 1996; Spring, 2009; Toot, 2013). Constant surveillance was perceived as anathema for carers that disrupted the sense of homeliness (Askham, 2007). Risk managing activities (such as locking or hiding hazardous objects, controlling objects and environment), being surrounded by nursing equipment, and lack of social visits were limiting home comfort for carers (de la Cuesta, 2005). The home was put in the service of the person with dementia to enable them to stay healthy and safe at home for longer, which impacted on carers' experience and comfort at home (de la Cuesta, 2005). For the person with dementia, the constant checking of the environment worrying that something might go wrong and that their safety will be jeopardised, was the reason affecting their peace and comfort at home (de Witt, 2009). Additionally the presence of supportive professionals was sometimes viewed as intrusive for both people with dementia who lived alone (Aminzadeh, 2010) and for carers (Dröes, 2006). Homes that provided the opportunities for privacy (e.g. creating retreat spaces for the person with dementia) were considered easier to provide care (Olsen, 1996) as carers needed to find a balance between monitoring and the 
need for some personal space and time. Use of different technologies was perceived with mixed feelings: some were considered as very valuable, providing freedom, reassurance and continuity at home (Kinney, 2003; Toot, 2013); some were viewed as a threat to privacy (Powell, 2010), or non-significant (Nygård, 2008).

1.3.2 Tension between familiarity versus adaptations: the findings indicated the need to keep the home familiar for the person with dementia to help optimise their functioning levels, and on the other hand to implement adaptations to promote safety and well being. Some carers feared causing confusion to their relative if they were to implement changes at home (de la Cuesta, 2005). Professionals also thought that home changes could cause confusion (Toot, 2013). This perception seemed to apply for established routines as carers perceived any deviation to their routines as negative (Redfern, 2002). Simple and practical adaptations, such as putting up railings, or installing a microwave, were considered appropriate as they did not threaten the independence of the person with dementia (Cott, 2013). The home environment could be enabling in the sense that it could encourage independence and engage the person with dementia in meaningful activities, but at the same time remain familiar and comfortable (Olsen, 1996). Some people with dementia saw simplifying and downsizing as a relief, as keeping the home as it used to be, became increasingly difficult to manage (Aminzadeh, 2010).

\subsubsection{Tension between risks versus independence: findings revealed tension between} preventing risks and encouraging independence and autonomy at home. Concerns over the safety of the person with dementia were the main reason that carers implemented risk strategies, although people with dementia living alone did not always recognise risk (Cott, 2013). Carers struggled to find risk-balancing strategies and constantly re-negotiate acceptable and unacceptable risks (Cott, 2013). Some carers, who were concerned with their relative's safety, decided to use controlling strategies (e.g. blocking, restricting access, and 
locking). Such strategies provided peace of mind for the carer, reduced uncertainty (Buri, 2000) and prevented risks (Nygård, 2002); however they also minimised the autonomy and ability of their relatives to move freely at home (Buri, 2000; Chung, 1997; Dodds, 1994; Olsen, 1996; Olsson, 2011). In some cases, because these strategies were either not easily acceptable to the person with dementia or challenging their independence and thus upsetting them, carers valued the independence of their relatives higher than the risk and chose not to implement the strategies (Cott, 2013). The use of technologies was considered to promote safety and ensure continuity of daily activities in a less restrictive environment (e.g. alarms), but in some cases restrict the independence (Kinney, 2003; Nygård, 2008). Some carers were more likely to use an assistive device to perform an activity safely, even if they are not completely satisfied with the device, for example a bathing device (Nochajski, 2013). Although safety is paramount, the findings indicated that the home environment could be enabling rather than unnecessarily restrictive in order to promote the strengths, independence and meaningful activities for the person with dementia (Olsen, 1996). Another strategy highlighted was to create safety zones within the home that the person with dementia could use safely (Olsen, 1996).

2. There is no magic formula. This theme reports that life at home with dementia can be unpredictable and ever changing and hence there is no magic solution to solve potential home challenges. Rather, adapting the home environment to meet both the needs of the person with dementia and their co-resident carer(s) is an ongoing, personalised and often improvised process. This theme also describes some environmental elements that are perceived as helpful in home dementia care.

2.1 The ongoing changing nature of home. The home environment becomes more challenging as the dementia progresses. The timing, way and extent that the home needs 
adapting depends largely on individual cases, influenced by the type of dementia, progress, type of housing, and finances. As a result, there is no unique solution or strategy (Olsen, 1996); rather adapting the home requires an ongoing and personalised procedure, and home needs to be a hybrid space to accommodate changes (de la Cuesta, 2005; Forbat, 2004; Olsen, 1996).

2.2 Useful home components. The included studies highlighted some general components in the home environment that would make life with dementia at home much easier. For example, the layout was perceived as important to make home totally accessible and adaptable to accommodate changes over time, especially at the later stages of dementia when both mobility and cognition can be severely affected (Olsen, 1996). This means enabling access to and within the house, for example accessing the entrance of the home or access to outdoors (Olsen, 1996). The bathroom needs to be accessible and spacious to accommodate adaptations, such as entering the bath/shower via aids or on wheelchair (Olsen, 1996). Accessible and adaptable design reduces emotional and physical demands for the carer, while encouraging comfort and independence for the person with dementia (Olsen, 1996). For people with dementia windows became focal points and provided company and access to the outside world (de Witt, 2009).

A useful layout was perceived as one that includes a toilet and shower located on the same level/floor (Forbat, 2004; Olsen, 1996), a ground floor laundry (Olsen, 1996), and is compact, easy and one level layout without stairs (Olsen, 1996). Multi-level design was perceived as unhelpful as it did not support easy surveillance (Askham, 2007) and stairs were perceived as a potential falls risk (Chung, 2013). Small and divided rooms were also perceived as unsupportive of supervision at home whereas an open layout was perceived as helpful because it enhances visibility and hence makes monitoring and interaction for the carer easier, and fosters reassurance for the person with dementia (Olsen, 1996; Askham, 
2007). However, in terms of safety, one study reported that closed off rooms (especially the kitchen) is ideal (Olsen, 1996).

Another crucial home element was to have adequate space. This was perceived to be important and therapeutic to: serve changing needs (de la Cuesta, 2005; Olsen, 1996), support caring by providing space for wandering safely (Olsen, 1996), afford retreat space for the person with dementia to sustain personhood (de la Cuesta, 2005), and provide an extra bedroom for carers to sleep if necessary as well as providing some privacy (Olsen, 1996). Caring in a small apartment or small house was perceived as difficult, whereas bigger space extended the duration of care in the home (de la Cuesta, 2005). However, a single study highlighted that some carers considered moving to a smaller accommodation as a better caring option (Lach, 2007).

2.3 Individualised strategies. Family carers adapted their space to: prevent harm, make the home practical and safe, promote autonomy, overcome architectural limitations (Chung, 2013; de la Cuesta, 2005), and preserve order (O’Donnell, 2000). In order to be effective, adaptive strategies need to be individualised (Richter, 1995) and responsive to specific situations (Redfern, 2002). Professionals reported that strategies needed to be geared to the changing needs of the person with dementia (Dröes, 2006).

2.4 Improvising strategies. Studies highlighted that carers had implemented various improvisations and tricks to tackle particular challenges at home related to safety, communication, and convenience. One study pointed to the resourcefulness of carers and their ability to create therapeutic possibilities in the home setting (de la Cuesta, 2005). Often carers became inventive via trial and error and without professional input (Chung, 2013; de la Cuesta, 2005; Kinney, 2003; Olsen, 1996; Richter, 1995). For example, many publications gave examples of how carers transformed household goods into safety features and/or technological objects, like coming up with their own safety alarms, i.e. adding door chimes 
(Buri, 2000; Chung, 1997; de la Cuesta, 2005; Olsen, 1996; Olsson, 2011; Smith, 2001). When personal and social resources were limited, carers had the extra burden of improvising solutions and equipment (de la Cuesta, 2005). One study reported that people with dementia themselves also invented their own solutions using technologies to overcome daily problems (Nygård, 2008).

3. Adapting the physical space, objects and behaviour. This theme collates a number of strategies proposed in the included studies to make life with dementia better at home. Adjusting the physical environment (spaces and objects) and behaviour was necessary to facilitate various aspects of daily life (occupations, communication, routines, autonomy), prevent or manage behavioural symptoms (wandering, confusion, agitation), facilitate care, surveillance, and home safety, and reduce carers' stress.

3.1 Transformative strategies: A widely reported strategy that was perceived as helpful in the reported studies was adjusting the home space and objects. This was implemented in order to provide space, supervision and comfort. Examples are: creating wider doorways, extending landings, repositioning objects and furniture, adjusting the light (especially night lights for orientation), changing the functions of rooms (for example to create retreat areas, secure outdoor decks, screen porches, relocate to another room), and adjusting the mirror to assist with monitoring (Askham, 2007; Buri, 2000; de la Cuesta, 2005; Dodds, 1994; Lach, 2007; Nochajski, 2013; Nygård, 2003; Olsen, 1996; Vikström, 2005).

3.2 Behavioural strategies. Maintaining familiarity, habits, regulated and simple routines, setting up systems, and keeping the aesthetic aspects and order in the environment (items and favourite furniture in specific locations) was important to carers and people with dementia (Askham, 2007; Buri, 2000; de la Cuesta, 2005; Dröes, 2006; Harris, 2006; Hogan, 2003; Nygård, 2002; Nygård, 2003; Nygård, 2008; Olsen, 1996; Olsson, 1998; Redfern, 
2002; Richter, 1995; Smith, 2001; Taşc1, 2012; Wherton, 2008). However, in one publication (Redfern, 2002) some carers mentioned that they objected to keeping the routine. In maintaining the home's aesthetics, religious objects and ornaments were considered to add a more home-like atmosphere (de la Cuesta, 2005) and compensate for the institutionalised look. Another study (Wherton, 2008) reported that unfamiliarity (e.g. new appliances with which the person with dementia would be unfamiliar) could be a useful strategy to prevent risk and minimise the likelihood of the people with dementia using them.

Apart from maintaining familiarity, a number of other controlling and monitoring strategies were reported in the included studies. These were: using furniture to block access (Dodds, 1994; Buri, 2000), controlling or locking the use of appliances (de la Cuesta, 2005; Nochajski, 2013; O’Donnell, 2000; Olsen, 1996; Smith, 2001; Taşc1, 2012; Toot, 2013; Yang, 1997), controlling water use and temperature (Lach, 2007; Olsen, 1996), controlling radiator temperature (van Hoof, 2009), locking the electric box (Yang, 1997), controlling or locking the exit/access to spaces and objects (Askham, 2007; de la Cuesta, 2005; de Witt, 2009; Dickson, 2012; Dodds, 1994; Lach, 2007; Nygård, 2002; O’Donnell, 2000; Olsen, 1996; Olsson, 2011; Richter, 1995; Smith, 2001; Taşc1, 2012), installing gates or folding doors (Olsen, 1996), using childproof locks (Olsen, 1996; Olsson, 2011), just shutting the door (Dodds, 1994), or removing keys from doors (O’Donnell, 2000). One study (Taşc1, 2012) reported that locking doors made the person with dementia panic. From the carers' perspective, leaving the door ajar (Buri, 2000) was also useful to monitor the person with dementia.

3.3 Subtractive strategies. These types of strategies included: removing items and replacing items (e.g. rugs, flooring), de-cluttering and house cleaning (Aminzadeh, 2010; de la Cuesta, 2005; Dickson, 2012; Lach, 2007; Olsen, 1996; Taşc1, 2012), hiding and disguising objects and spaces (Lach, 2007; Olsen, 1996), reducing distractions and avoiding exposure to 
irrelevant or multiple (visual and/or auditory) stimuli (Nygård, 2002; Richter, 1995; van Hoof, 2009; Vikström, 2005). A home environment which is too noisy or too busy was considered negative (Dröes, 2006).

3.4 Additive strategies. This subtheme involves two main additive strategies: (1) compensating using senses and (2) the introduction of assistive devices and equipment. Compensating via senses included using auditory, tactile and visual cues as reminders (Nygård, 2002; Nygård, 2003) to support the person with dementia with memory problems and engaging in tasks. Visual cues were particularly reported as easy and helpful, such as, leaving objects (e.g. pills, clothes) in the open (Cott, 2013; Nygård, 2002; Redfern, 2002; Wherton, 2008; Vikström, 2005), leaving notes on a diary, calendar and/or on a board (Boger, 2013; Nockajski, 2013; Nygård, 2002; Nygård, 2003; Wherton, 2008), using signs, labels, and pictures (Askham, 2007; Boger, 2013; Dodds, 1994; Drennan, 2011; Lach, 2007; Nockajski, 2013; Olsson, 2011; Rosenberg, 2012; Toot, 2013; Yang, 1997). However, one study (Nochajski, 2013) mentioned that labelling was a helpful visual strategy only at the early stages of dementia. In some cases, colour was helpful in finding items easily (Boger, 2013; Nygård, 2003; Olsen, 1996;). In terms of acceptability, two studies reported that carers disliked some visual tools such as communication books and reality orientation calendars (Nochajski, 2013), and orientation / location pictures, for example pictures of toilets (Drennan, 2011).

For people with dementia, television and radio provided company and a means of connecting with the outside world (de Witt, 2009). Music was used to motivate and engage people with dementia in daily activities and/or offer mental stimulation and reminiscence (Baker, 2012; Chung, 2013; de la Cuesta, 2005; Sixsmith, 2007), and to enhance both the carers' and the relatives' mood and wellbeing (Baker, 2012; Chung, 2013; O'Donnell, 2000; Sixsmith, 2007). A single study (Chung, 2013) reported that using music was not found 
helpful for the person with dementia. Finally, in terms of the olfactory environment, room sprays were used by carers to cover unpleasant smells (Drennan, 2001).

The second additive strategy was introducing technologies (everyday and specialist assistive devices) and equipment. Everyday technologies, for example microwaves, torch, washing-machines (Boger, 2013; Kinney, 2003; Nygård, 2008; Powell, 2010; van Hoof, 2009), and a variety of alerting devices (including baby monitors, intercoms, alarms, pagers, telecare and security systems with motion detectors, fire and gas detectors) were highlighted in included studies (de la Cuesta, 2005, Dickson, 2012; Forbat, 2004; Kinney, 2003; Lach, 2007; Olsson, 2011; Powell, 2010; Toot, 2013; Yang, 1997). Reminding devices (such as medication dispensers, timers, time orientation devices and computers) were a useful resource for people with dementia and their carers (Boger, 2013; de Witt, 2009; Harris, 2006; Nochajski, 2013; Nygård, 2002; Nygård, 2008; Rosenberg, 2012). However, studies highlighted mixed perceptions over the usefulness of technologies depending on context and need (Kinney, 2003; Nygård, 2008; Nygård, 2002), as some devices were regarded as too complicated to be used by the people with dementia (Nygård, 2008, Rosenberg, 2012; Wherton, 2008), especially if perceived as stigmatising and not embodied in daily routines (Rosenberg, 2012). An electronic calendar is an example of this with some studies reporting users' satisfaction (Boger, 2013; Rosenberg, 2012;) and some not (Nochajski, 2013). Similarly, television was perceived as offering mental stimulation, company and comfort for some people with dementia (Boger, 2013; Buri, 2000; Chung, 2013; de Witt, 2009; Dickson, 2012; Dodds, 1994), whereas for some it was perceived as too difficult to follow (Nygård, 2002; Richter, 1995). Additionally, carers mentioned that they liked 'low-tech' solutions (Powell, 2010), and some rejected falls detectors (Boger, 2013), alarms (Yang, 1997), and medication devices (Kinney, 2003; Nochajski, 2013). 
In addition the use of equipment was highlighted as a useful strategy, including bathing and toileting equipment, such as handrails, grab rails, hydraulic bath lift, roll-in or walk-in shower, bath bench, hand-held shower, portable grab rail, shower bar and seat, commodes, and raised toilet seats (Dickson, 2012; Drennan, 2011; Forbat, 2004; Lach, 2007; Nochajski, 2013; Olsen, 1996; Smith, 2001; Yang, 1997). A range of other equipment was reported as useful, such as hospital beds (Chung, 2013; Olsen, 1996; Smith, 2001; Yang, 1997), furniture and mattress coverings and incontinence pads (Drennan, 2011), handrails and bannisters around the home (Olsen, 1996), bed and chair lifts (Drennan, 2011), walkers (Nochajski, 2013), ramps (Olsen, 1996; Smith, 2001), and special chairs (Olsen, 1996). One study (Forbat, 2004) reported that the lack of grab rails is a barrier adding to the carers' burden. Although generally acknowledged that equipment enhances independence and functionality, studies also reported that some carers perceived some equipment (e.g. the handheld shower, bed guard, bath bench) as unhelpful (Cott, 2013; Nochajski, 2013), or unacceptable, for example, the commodes (Drennan, 2011). Studies also reported that people with dementia might not recognise (Noskajski, 2013) or like some equipment, for example, the hospital bed (Chung, 2013) and the raised toilet seat (Cott, 2013).

\section{Discussion}

This review aimed to gather evidence on how people with dementia and their carers experience their home environment and how best to provide a dementia- and caring- friendly home environment. We set out to understand the key barriers and facilitators for caring for a person with dementia at home. As highlighted in the findings, home is a very important setting and is likely to change significantly over the progressive course of dementia. Broadly speaking, there is no panacea or magic solution. Dementia presents with unique vulnerabilities, which added to an individual's situation and the residence's characteristics, 
makes it difficult to draw conclusions on what may be the definitive barriers and facilitators. However, this review highlighted a number of environmental elements that considerably affect life at home: the home's accessibility, size, layout and general aesthetics. For example, homes without stairs, with adequate light and windows to outside, with an open floor plan for easy surveillance, but also with retreat areas for privacy for the person with dementia and the co-resident carer(s), are generally regarded as helpful.

The findings also highlighted that the home environment is a very useful element in dementia care that should not be underestimated. It can offer some easily implemented and low cost strategies (e.g. labelling cupboards, covering mirrors), but it can also be ideal for reminiscence activities as it is full of cherished objects and photographs, a finding consistent with previous quantitative studies (Gitlin et al., 2003; Gitlin, 2007; Safran-Norton, 2010; van Hoof \& Kort, 2009; Wherton \& Monk, 2008). The majority of the environmental strategies were perceived as helpful, although there were some exceptions. This may reflect the idea that there are large individual differences and strategies can be useful to some people when dealing with certain difficulties in certain stages of dementia. Perhaps when strategies become too complicated or time consuming, they would not be perceived as useful. It may also indicate that people follow professional recommendations, without considering them helpful, perhaps because they perceive them as stigmatising or not satisfying their personal circumstances and needs (Cott \& Tierney, 2013; Forchhammer, 2006).

In creating an enabling environment, people with dementia and carers may experience a number of tensions resulting from competing imperatives (e.g. safety versus comfort). There is often a fine line between balancing safety, independence, respect, and privacy while considering the needs of all inhabitants. For example, it has been suggested that blocking by using furniture may be an easy way to prevent risks but it can also be dangerous as it gives the 
false impression of safety and if used inappropriately it may result in restricting one's ability to move about freely (Buri \& Dawson, 2000).

\section{Strengths and Limitations}

This review offers two unique contributions. It is the first review to present up-to-date evidence on the barriers and facilitators of the home environment in dementia care. The review examined the impact of the home environment in a holistic way, examining various housing aspects (e.g. layout, size), environmental strategies (e.g. use of lighting, assistive technologies), as well as the personal experiences of how the home environment might change for people with dementia and carers. Incorporating international publications and searching databases that included grey literature (e.g. dissertations, conference proceedings, reports), this review provides compelling evidence to assist people with dementia, their families, and health and social care professionals in creating an enabling home environment. The systematic and comprehensive search, the inclusion of a large number of studies (the majority of high quality) and the strong principle themes (even after performing the sensitivity analysis) that were also validated by public engagement, suggest that the findings are robust. Thematic synthesis was used to analyse the included studies, which is a wellrecognised method. The themes of this review align with the environmental press theory that argues that environmental demands are inextricably linked to the individual's needs and hence the environment needs to be modified to match individual competences and challenges (Wahl \& Weisman, 2003). The findings of this review offer further evidence for this theory's applicability in dementia care and research.

This review has some limitations that are worth considering. The subjective nature of qualitative research means that many issues may not have been reported or missed in the 
publications and/or in our synthesis. Some studies reported positive appraisal of implemented environmental strategies, however researchers were not able to observe and confirm the actual use of these, as the majority of studies used traditional (sedentary) interviews. Although we included German and Greek studies, the majority of the studies retrieved were in English and this might have limited the included data and thus findings may be relevant only to specific participants and cultures. We did not contact key authors and organisations directly to gain further information as initially intended, due to resource constraints. Included studies were published from 1994 to 2013, covering a period of 20 years of research. Updated legislation and technological achievements suggests that practices may have changed since the earlier studies, and perhaps some of the strategies are now obsolete.

Thematic synthesis has been accused of de-contextualising findings as reviewers interpret themes from one setting to another, which may not be applicable. Thomas \& Harden (2008) argued that reviewers need to check whether their themes can be transferable and valid and also that the readers need to judge if the context of the synthesis is useful to their own situation. Because some of the included studies did not score highly in quality assessment, and some lacked information on methodological aspects (e.g. recruitment and analytical methods), this might have affected the depth and relevance of the findings of these studies. Particularly, the relationship between researcher and participants was not reported in the vast majority of the included studies that may have affected the validity, which is a significant limitation. Thus, generalisation is limited as these findings may be relevant only to specific populations. However, the broad themes of this review were discussed in a workshop with family carers, who offered some confirmation of transferability.

Finally, we aimed to include international qualitative literature to enable comparisons across different cultures and countries, which was not feasible. From the included studies, only 15 reported the ethnicity of participants, which did not allow a rigorous comparison. 


\section{Implications for practitioners}

This review examined the importance of the home environment in dementia care and support. Our findings are unlikely to be applicable to all people with dementia and their families but could provide guidance and ideas for acceptable ways to promote a dementiaand caring- friendly home environment. The uniqueness and progressive nature of dementia dictates that one technique that may work today, may need to be adapted or not be working by next month. Similarly, what works for one individual, may be unacceptable for another. Health and social care professionals should be careful when suggesting adaptations for carers and people with dementia, bearing in mind the stage, meanings, preferences and readiness of the users. Adaptations and assistive devices should be introduced within an individualised context that fits the person's values and routines and with appropriate timing. It is necessary that users understand the strategies and accept the need for their use, feel in control, and incorporate them in their daily routine; otherwise they are likely to reject them. This perhaps becomes more complex and challenging when practitioners have to balance the needs and preferences of people with dementia and those of their residing carers.

There is also need for more guided information and education on available strategies and devices and a continuous assessment of needs for both the carer and the person with dementia to support them throughout the journey. In their daily battle to maintain order and safety at home, carers assume the role of a psychologist (evaluating their relatives' mood and behaviour), therapist (engaging their relatives in meaningful activities), nurse (administering medication and hands-on care) and engineer (improvising technical solutions), in addition to taking up extra roles and responsibilities in their household (e.g. cooking, cleaning). Not forgetting that this group of carers are likely to be of older age, perhaps reluctant to accept professional help (Cameron, Aggar, Robinson, \& Kurrle, 2011), it is not surprising that they are likely to experience more stress and burden than other types of carers (Argimon et al., 
2004), which suggests that ongoing support is needed. Unmet needs of family carers may impact on their ability to provide care for longer (Afram et al., 2014). Individually tailored continuous assessment and support could enable people with dementia to stay in place for longer without adding additional burden to the carer to monitor and adapt the home environment, and without reaching the point of using extreme controlling strategies, which are not endorsed by professional bodies. Furthermore, there is a need to reach people with dementia and their carers in time and increase their awareness of potential environmental strategies, and how to manipulate the environment in different ways and in different stages.

The findings of this review also offer evidence to housing policy makers, commissioners and architects, who need to take into consideration the unique challenges of dementia and consider important home components, such as adequate size, layout and accessibility. By considering these aspects, future housing should be more ageing and caring friendly to correspond to the needs of our ageing society. Future carers will clearly benefit from the adaptability and hybridity of their homes and people with dementia could enjoy a better quality of life at home.

\section{Future research}

This review identified very little research on the meaning of home for carers of people with dementia. It was surprising that not many studies examined the views of health and social care professionals on the role of the home environment in dementia care. Future research should involve carers and practitioners to bring more light into their perspectives, as they are key in promoting strategies. It would also be helpful to investigate the various tensions experienced within the home, for example how carers make decisions over the strategies used and the potential ethical dimensions of these decisions. When involving people with dementia, researchers should present details of the relationship between them and the 
participants to add validity to findings. Most of the studies included in this review were focused on safety promotion. Future research should also look for elements promoting comfort in addition to safety in order to address all aspects of the home experience for both people with dementia and their family carers. Also of interest would be a study to explore the role of home space, acceptable strategies and the meaning of home for minority ethnic groups. Future research should address the barriers to adopting professionals' recommendations and implementing environmental strategies, and ways to promote continuous formal services. Future studies could also benefit from the use of walking interviews (Carpiano, 2009), a useful method to contextualise participants' lived experiences and overcome any uncertainties over the actual use of discussed strategies. The direct observation afforded by walking interviews removes any speculation of whether participants actually use solutions or are merely giving the 'right' answer.

\section{Acknowledgements}

This review is a part of a $\mathrm{PhD}$ studentship, which was partly funded by the Faculty of Science, University of Portsmouth, UK

We are grateful to Professor Alan Costall for his continuous support and helpful feedback on this manuscript.

\section{Declaration of Conflicting Interests}

The authors declare that there is no conflict of interest 


\section{References}

Afram, B., Verbeek, H., Bleijlevens, M. H. C., \& Hamers, J. P. H. (2015). Needs of informal caregivers during transition from home towards institutional care in dementia: a systematic review of qualitative studies. International Psychogeriatrics, 27(6), 891-902. doi:10.1017/S1041610214002154

Alzheimer's Society. (2014). Dementia UK: Update. London: Alzheimer's Society.

Argimon, J. M., Limon, E., Vila, J., \& Cabezas, C. (2004). Health-related quality of life in carers of patients with dementia. Family Practice, 21(4), 454-7. doi:10.1093/fampra/cmh418

Banerjee, S., Murray, J., Foley, B., Atkins, L., Schneider, J., \& Mann, A. (2003). Predictors of institutionalisation in people with dementia. Journal of Neurology, Neurosurgery \& Psychiatry, 74(9), 1315-1316. doi:10.1136/jnnp.74.9.1315

Barroso, J., Gollop, C. J., Sandelowski, M., Meynell, J., Pearce, P. F., \& Collins, L. J. (2003). The Challenges of searching for and retrieving qualitative studies. Western Journal of Nursing Research, 25(2), 153-178. doi:10.1177/0193945902250034

Bradshaw, S. A., Playford, E. D., \& Riazi, A. (2012). Living well in care homes: a systematic review of qualitative studies. Age and Ageing, 41, 1-12. doi:10.1093/ageing/afs069

Brodaty, H., Green, A., \& Koschera, A. (2003). Meta-analysis of psychosocial interventions for caregivers of people with dementia. Journal of American Geriatric Society, 51, 657664. doi:10.1034/j.1600-0579.2003.00210.x

Bunn, F., Goodman, C., Sworn, K., Rait, G., Brayne, C., Robinson, L., ... Iliffe, S. (2012). Psychosocial factors that shape patient and carer experiences of dementia diagnosis and treatment: A systematic review of qualitative studies. PLoS Medicine, 9(10), e1001331. doi:10.1371/journal.pmed.1001331 
Buri, H., \& Dawson, P. (2000). Caring for a relative with dementia: A theoretical model of coping with fall risk. Health, Risk \& Society, 2(3), 283-293. doi:10.1080/713670166

Cameron, I. D., Aggar, C., Robinson, a. L., \& Kurrle, S. E. (2011). Assessing and helping carers of older people. $B M J, 343$, d5202. doi:10.1136/bmj.d5202

Carpiano, R. M. (2009). Come take a walk with me: the "go-along" interview as a novel method for studying the implications of place for health and well-being. Health \& Place, 15(1), 263-72. doi:10.1016/j.healthplace.2008.05.003

Carroll, C., \& Booth, A. (2015). Quality assessment of qualitative evidence for systematic review and synthesis: Is it meaningful, and if so, how should it be performed? Research Synthesis Methods, 6, 149-154. doi:10.1002/jrsm.1128

Chung, J., \& Lai, C. (2009). Snoezelen for dementia (Review). The Cochrane Library, (1), 143. doi:10.1002/14651858.CD003152

Cooke, D. D., McNally, L., Mulligan, K. T., Harrison, M. J., Newman, S. P., Harrison, J. G., \& Newman, S. P. (2001). Psychosocial interventions for caregivers of people with dementia: a systematic review. Aging \& Mental Health, 5(2), 120-135. doi:10.1080/13607860120038302

Cott, C. A., \& Tierney, M. C. (2013). Acceptable and unacceptable risk: balancing everyday risk by family members of older cognitively impaired adults who live alone. Health Risk \& Society, 15(5, SI), 402-415. doi:10.1080/13698575.2013.801936

Day, K., Carreon, D., \& Stump, C. (2000). The therapeutic design of environments for people with dementia: a review of the empirical research. The Gerontologist, 40(4), 397-416. doi:10.1093/geront/40.4.397

Dixon-Woods, M., Agarwal, S., Young, B., Jones, D., \& Sutton, A. (2004). Integrative approaches to qualitative and quantitative evidence. London: NHS Health Development Agency. 
Drahota, A., Ward, D., Mackenzie, H., Stores, R., Higgins, B., Gal, D., \& Dean, T. (2012). Sensory environment on health-related outcomes of hospital patients (Review). The Cochrane Library, (3), 1-362. doi:10.1002/14651858.CD005315.pub2.

Dugmore, O., Orrell, M., \& Spector, A. (2015). Qualitative studies of psychosocial interventions for dementia: a systematic review. Aging \& Mental Health, 19(11), 1-13. doi:10.1080/13607863.2015.1011079

Evans, D., \& Lee, E. (2014). Impact of dementia on marriage: a qualitative systematic review. Dementia, 13(3), 330-49. doi:10.1177/1471301212473882

Forbes, D., Blake, C., Thiessen, E., Peacock, S., \& Hawranik, P. (2014). Light therapy for improving cognition, activities of daily living, sleep, challenging behaviour, and psychiatric disturbances in dementia (Review). The Cochrane Library, (2), 1-62. doi:10.1002/14651858.CD003946.pub4.

Forchhammer, H. B. (2006). The woman who used her walking stick as a telephone: The use of utilities in praxies. In A. Costall \& O. Dreier (Eds.), Doing things with things. The design and use of everyday objects (pp. 131-146). Oxon: Routledge.

Garcia, L. J., Kartolo, A., \& Méthot-Curtis, E. (2012). A discussion of the use of virtual reality in dementia. In C. Eichenberg (Ed.), Virtual Reality in Psychological, Medical and Pedagogical Applications (pp. 123-136). Intech.

Gitlin, L. N. (2007). Guidelines for environmental adaptations and safety at home. Alzheimer's Care Today, 8(3), 278-281. Retrieved from http://search.ebscohost.com/login.aspx?direct=true \&db=cin20\&AN=2010202920\&site= ehost-live

Gitlin, L. N., \& Corcoran, M. (1996). Managing dementia at home: The role of home environmental modifications. Topics in Geriatric Rehabilitation, 12(2), 28-39. Retrieved from 
http://journals.lww.com/topicsingeriatricrehabilitation/Abstract/1996/12000/Managing_ Dementia_at_Home_The_Role_of_Home.6.aspx

Gitlin, L. N., Liebman, J. M., \& Winter, L. (2003). Are environmental interventions effective in the management of Alzheimer's disease and related disorders?: A synthesis of the evidence. Alzheimer's Care Quarterly, 4(2), 85-107. Retrieved from http://journals.lww.com/actjournalonline/Abstract/2003/04000/Are_Environmental_Inter ventions_Effective_in_the.3.aspx

Holt, F., Birks, T., Thorgrimsen, M., Spector, A., Wiles, A., Orrell, M., ... Barton Wright, P. (2009). Aroma therapy for dementia (Review). The Cochrane Library, (1), 1-22. doi:10.1002/14651858.CD003150

Kahana, E., Lovegreen, L., Kahana, B., \& Kahana, M. (2003). Person, environment, and person-environment fit as influences on residential satisafaction of elders. Environment and Behavior, 35(3), 434-453. doi:10.1177/0013916503035003007

Lai, C. K. C., Yeung, J. J. H., Mok, V., \& Chi, I. (2009). Special care units for dementia individuals with behavioural problems (Review). The Cochrane Library, (4), CD006470. doi:10.1002/14651858.CD006470.pub2

Lawton, M. P. (1990). Residential environment and self-directedness among older people. American Psychologist, 45(5), 638-640. doi:10.1037/0003-066X.45.5.638

Luengo-Fernandez, R., Leal, J., \& Gray, A. (2010). Dementia 2010: The economic burden of dementia and associated research funding in the United Kingdom. Oxford: Alzheimer's Research Trust.

Moniz Cook, E., Swift, K., James, I., Malouf, R., De Vugt, M., \& Verhey, F. (2012). Functional analysis-based interventions for challenging behaviour in dementia (Review). The Cochrane Library, (2), 1-125. doi:10.1002/14651858.CD006929.pub2. 
Nguyen, Q., \& Paton, C. (2008). The use of aromatherapy to treat behavioural problems in dementia. International Journal of Geriatric Psychiatry, 23, 337-346. doi:10.1002/gps

Parker, D., Mills, S., \& Abbey, J. J. (2008). Effectiveness of interventions that assist caregivers to provide support people with dementia living in the community: a systematic review. International Journal of Evidence-Based Healthcare, 6, 137-172. doi:10.1111/j.1479-6988.2008.00090.x

Petersson, I., Lilja, M., \& Borell, L. (2012). To feel safe in everyday life at home - a study of older adults after home modifications. Ageing and Society, 32(5), 791-811. doi:http://dx.doi.org/10.1017/S0144686X11000614

Pinquart, M., \& Sorensen, S. (2006). Helping caregivers of persons with dementia: which interventions work and how large are their effects? International Psychogeriatrics, 18(4), 577-595. doi:http://dx.doi.org/10.1017/S1041610206003462

Pope, C., \& Mays, N. (2006). Qualitative research in health care (3rd ed.). Oxford England: Blackwell Publishing Ltd.

Price, J., Hermans, D., \& Grimley Evans, J. (2009). Subjective barriers to prevent wandering of cognitively impaired people (Review). The Cochrane Library, (3). doi:10.1002/14651858.CD001932

Prince, M., Wimo, A., Guerchet, M., Gemma-Claire, A., Wu, Y.-T., \& Prina, M. (2015). World Alzheimer Report 2015: The Global Impact of Dementia - An analysis of prevalence, incidence, cost And trends. London. doi:10.1111/j.0963-7214.2004.00293.x

Robinson, L., Hutchings, D., Corner, L., Beyer, F., Dickinson, H., Vanoli, A., ... Bond, J. (2006). A systematic literature review of the effectiveness of non-pharmacological interventions to prevent wandering in dementia and evaluation of the ethical implications and acceptability of their use. Health Technology Assessment, 10(26), 1-126. doi:http://dx.doi.org/10.3310/hta10260 
Safran-Norton, C. E. (2010). Physical home environment as a determinant of aging in place for different types of elderly households. Journal of Housing for the Elderly, 24(2), 208231. doi:10.1080/02763891003757494

Saini, M., \& Shlonsky, A. (2012). Systematic synthesis of qualitative research. New York: Oxford University Press.

Soilemezi, D., Drahota, A., Stores, R., \& Crossland, J. (2013). The role of the home environment when caring for a person with dementia: a synthesis of qualitative studies. Retrieved from http://www.crd.york.ac.uk/PROSPERO/display_record.asp?ID=CRD42013004260

Soril, L. J. J., Leggett, L. E., Lorenzetti, D. L., Silvius, J., Robertson, D., Mansell, L., ... Clement, F. M. (2014). Effective use of the built environment to manage behavioural and psychological symptoms of dementia: a systematic review. PloS One, 9(12), e115425. doi:10.1371/journal.pone.0115425

Steeman, E., Casterle, B. D. De, Godderis, J., \& Grypdonck, M. (2006). Living with earlystage dementia: a review of qualitative studies. Journal of Advanced Nursing, 54(6), 722-738. doi:10.1111/j.1365-2648.2006.03874.x

Thomas, J., \& Harden, A. (2008). Methods for the thematic synthesis of qualitative research in systematic reviews. BMC Medical Research Methodology, 8, 45. doi:10.1186/1471$2288-8-45$

Torrington, J. M., \& Tregenza, P. R. (2007). Lighting for people with dementia. Lighting Research and Technology, 39(1), 81-97. doi:10.1177/1365782806074484

Torti, F. M., Gwyther, L. P., Reed, S. D., Friedman, J. Y., \& Schulman, K. A. (2004). A multinational review of recent trends and reports in dementia caregiver burden. Alzheimer Disease and Associated Disorders, 18(2), 99-109. Retrieved from http://www.ncbi.nlm.nih.gov/pubmed/15249854 
Unwin, B. K., Andrews, C. M., Andrews, P. M., \& Hanson, J. L. (2009). Therapeutic home adaptations for older adults with disabilities. American Family Physician, 80(9), 963968. Retrieved from http://www.aafp.org/afp/2009/1101/p963.html

van der Roest, H. G., Meiland, F. J. M., Maroccini, R., Comijs, H. C., Jonker, C., \& Dröes, R.-M. (2007). Subjective needs of people with dementia: a review of the literature. International Psychogeriatrics, 19(03), 559. doi:10.1017/S1041610206004716 van Hoof, J., \& Kort, H. S. M. (2009). Supportive living environments: a first concept of a dwelling designed for older adults with dementia. Dementia, 8(2), 293-316. doi:10.1177/1471301209103276

van Hoof, J., Kort, H. S. M., van Waarde, H., \& Blom, M. M. (2010). Environmental interventions and the design of homes for older adults with dementia: an overview. American Journal of Alzheimer's Disease and Other Dementias, 25(3), 202-32. doi:10.1177/1533317509358885

Vink, A., Bruinsma, M., \& Scholten, R. (2011). Music therapy for people with dementia (Review). The Cochrane Library, (3), 1-49. doi:10.1002/14651858.CD003477.pub2

Wahl, H.-W., \& Weisman, G. D. (2003). Environmental gerontology at the beginning of the new millennium: reflections on its historical, empirical, and theoretical development. The Gerontologist, 43(5), 616-27. Retrieved from http://www.ncbi.nlm.nih.gov/pubmed/14570958

Wherton, J. P., \& Monk, A. F. (2008). Technological opportunities for supporting people with dementia who are living at home. International Journal of Human-Computer Studies, 66(8), 571-586. doi:10.1016/j.ijhcs.2008.03.001

Wilczynski, N. L., Marks, S., \& Haynes, R. B. (2007). Search strategies for identifying qualitative studies in CINAHL. Qualitative Health Research, 17(5), 705-710. doi:10.1177/1049732306294515 
Wong, S. S., Wilczynski, N. L., \& Haynes, R. B. (2004). Developing optimal search strategies for detecting clinically relevant qualitative studies in MEDLINE. Studies in Health Technology and Informatics, 107(Pt 1), 311-6. Retrieved from http://www.ncbi.nlm.nih.gov/pubmed/15360825

World Health Organisation. (2012). Dementia: a public health priority. Geneva.

Zarit, S. H., Gaugler, J. E., \& Jarrott, S. E. (1999). Useful services for families: research findings and directions. International Journal of Geriatric Psychiatry, 14(3), 165-77; discussion 178-81. doi:10.1002/(SICI)1099-1166(199903)14:3<165::AIDGPS966>3.0.CO;2-O 


\section{Tables}

\section{Table 1. Search Terms Used}

\begin{tabular}{|l|l|}
\hline S1 & $\begin{array}{l}{[\text { dement* or Alzheimer*] AND [vascular OR old* OR elderly OR geriatric* }} \\
\text { OR disab* or disabil*] }\end{array}$ \\
\hline S2 & $\begin{array}{l}\text { [family car* OR carer* OR caregiv*] } \\
\text { thealth* personnel OR health* practitioner* OR formal car* OR occupational }\end{array}$ \\
\hline S4 & $\begin{array}{l}{[\text { home* environment* OR domestic environment* OR physical }} \\
\text { environment* OR residen* OR design* OR atmosphere OR } \\
\text { architectureindependent living OR home modification* OR home adapt* OR } \\
\text { environmental intervention* OR smart home OR equipment OR assist* } \\
\text { technolog* OR ageing in place OR aging in place] }\end{array}$ \\
\hline S6 & $\begin{array}{l}\text { [interview* OR qualitative* OR interview* OR audiorecord* OR grounded } \\
\text { theory OR thematic analysis OR focus group* OR finding* OR discourse } \\
\text { analysis OR content analysis OR phenomenology OR synthesis OR } \\
\text { perception OR experienc* OR attitude* OR saturat* OR theme* OR } \\
\text { narrative* OR view*] }\end{array}$ \\
\hline
\end{tabular}


Table 2. Characteristics of Included Studies $(N=40)$

\begin{tabular}{|c|c|c|c|c|c|c|c|c|c|c|c|c|}
\hline No & Study ID & $\begin{array}{l}\text { Year study } \\
\text { conducted }\end{array}$ & Country & Participants & Age & Gender & Ethnicity & $\begin{array}{l}\text { Stage of } \\
\text { dementia }\end{array}$ & Type of carer & Main focus & $\begin{array}{l}\text { Research } \\
\text { method }\end{array}$ & $\begin{array}{l}\text { Type of } \\
\text { analysis }\end{array}$ \\
\hline 1 & $\begin{array}{l}\text { Aminzadeh, } \\
2010\end{array}$ & $\begin{array}{l}\text { not } \\
\text { reported }\end{array}$ & Canada & $\begin{array}{l}16 \text { people with } \\
\text { dementia }\end{array}$ & 76 to $93(M=85.3)$ & 11 female, 5 male & $\begin{array}{l}12 \text { Canadian, } 3 \\
\text { Europeans \& } 1 \\
\text { Asian }\end{array}$ & $\begin{array}{l}2 / 3 \text { in mild, } \\
\text { the rest } \\
\text { moderate }\end{array}$ & $\mathrm{n} / \mathrm{a}$ & $\begin{array}{l}\text { meanings and } \\
\text { significance of } \\
\text { home for people } \\
\text { with dementia }\end{array}$ & $\begin{array}{l}\text { in-depth face- } \\
\text { to-face home } \\
\text { interviews }\end{array}$ & $\begin{array}{l}\text { grounded } \\
\text { theory }\end{array}$ \\
\hline 2 & $\begin{array}{l}\text { Askham, } \\
2007\end{array}$ & $\begin{array}{l}\text { not } \\
\text { reported }\end{array}$ & UK & $\begin{array}{l}20 \text { couples of } \\
\text { people with } \\
\text { dementia and } \\
\text { their carers }\end{array}$ & $\begin{array}{l}\text { people with } \\
\text { dementia: } 74 \text { to } 96 \\
(M=85) \text {; spouse } \\
\text { carers: } 75 \text { to } 87 \\
(M=79) \text {, children } \\
\text { or other: } 50-68 \\
(M=57)\end{array}$ & $\begin{array}{l}\text { people with } \\
\text { dementia: } 15 \\
\text { women, } 5 \text { men; } \\
\text { carers: } 14 \text { women, } \\
6 \text { men }\end{array}$ & not reported & $\begin{array}{l}\text { mild to } \\
\text { severe }\end{array}$ & $\begin{array}{l}9 \text { spouses, } 4 \\
\text { children, } 1 \\
\text { friend, } 1 \\
\text { neighbour, } 1 \\
\text { daughter-in-law, } \\
1 \text { nephew, } 1 \\
\text { niece }\end{array}$ & $\begin{array}{l}\text { care at home for } \\
\text { people with } \\
\text { dementia }\end{array}$ & $\begin{array}{l}\text { depth } \\
\text { interviews \& } \\
\text { non-participant } \\
\text { observation }\end{array}$ & $\begin{array}{l}\text { constant } \\
\text { comparison }\end{array}$ \\
\hline 3 & Baker, 2012 & $\begin{array}{l}\text { not } \\
\text { reported }\end{array}$ & Australia & $\begin{array}{l}5 \text { couples of } \\
\text { people with } \\
\text { dementia and } \\
\text { their carers }\end{array}$ & $\begin{array}{l}\text { carers: } 59 \text { to } 81 \text {; } \\
\text { people with } \\
\text { dementia: } 59 \text { to } 88\end{array}$ & $\begin{array}{l}\text { carers: } 3 \text { female, } 2 \\
\text { male; people with } \\
\text { dementia: } 2 \\
\text { female, } 3 \text { male }\end{array}$ & not reported & $\begin{array}{l}\text { not } \\
\text { reported }\end{array}$ & all spouses & $\begin{array}{l}\text { evaluate music } \\
\text { intervention in } \\
\text { relation to couple's } \\
\text { relationship }\end{array}$ & $\begin{array}{l}\text { scales, diaries } \\
\& \text { interviews }\end{array}$ & $\begin{array}{l}\text { thematic } \\
\text { analysis }\end{array}$ \\
\hline 4 & Boger, 2013 & 2010 & Canada & $\begin{array}{l}3 \text { family } \\
\text { carers, } 10 \\
\text { occupational } \\
\text { therapists }\end{array}$ & $\begin{array}{l}\text { carers: } 2 \text { between } \\
50-59,1 \text { over } 80\end{array}$ & $\begin{array}{l}\text { carers \& } \\
\text { occupational } \\
\text { therapists: females }\end{array}$ & not reported & $\begin{array}{l}\text { not } \\
\text { reported }\end{array}$ & $\begin{array}{l}2 \text { spouses, } 1 \text { adult } \\
\text { child }\end{array}$ & $\begin{array}{l}\text { use of assistive } \\
\text { technologies to } \\
\text { support daily } \\
\text { occupations }\end{array}$ & $\begin{array}{l}\text { semi-structure } \\
\text { interviews }\end{array}$ & $\begin{array}{l}\text { visually } \\
\text { analysed } \\
\text { with } \\
\text { frequencies }\end{array}$ \\
\hline 5 & Buri, 2000 & 1996 & UK & 6 family carers & not reported & $\begin{array}{l}\text { carers: } 3 \text { male, } 3 \\
\text { female }\end{array}$ & not reported & $\begin{array}{l}\text { moderate } \\
\text { to severe }\end{array}$ & $\begin{array}{l}1 \text { spouse, } 3 \\
\text { daughters, } 2 \\
\text { sons-in-law }\end{array}$ & $\begin{array}{l}\text { meanings of falls } \\
\text { risk in elderly } \\
\text { persons with } \\
\text { dementia }\end{array}$ & $\begin{array}{l}\text { focus group, } \\
\text { individual } \\
\text { unstructured } \\
\text { home } \\
\text { interviews }\end{array}$ & $\begin{array}{l}\text { content } \\
\text { analysis }\end{array}$ \\
\hline 6 & Chung, 1997 & $\begin{array}{l}\text { not } \\
\text { reported }\end{array}$ & $\begin{array}{l}\text { Hong } \\
\text { Kong }\end{array}$ & $\begin{array}{l}15 \text { family } \\
\text { carers }\end{array}$ & 28 to 79 & 4 male, 11 female & not reported & $\mathrm{n} / \mathrm{a}$ & $\begin{array}{l}8 \text { spouses, } 6 \\
\text { daughter, } 1 \\
\text { granddaughter }\end{array}$ & meanings of caring & $\begin{array}{l}2 \text { semi- } \\
\text { structured } \\
\text { focus groups }\end{array}$ & $\begin{array}{l}\text { content } \\
\text { analysis }\end{array}$ \\
\hline
\end{tabular}


Table 2. Continued

\begin{tabular}{|c|c|c|c|c|c|c|c|c|c|c|c|c|}
\hline No & Study ID & $\begin{array}{l}\text { Year } \\
\text { study } \\
\text { conducted }\end{array}$ & Country & Participants & Age & Gender & Ethnicity & $\begin{array}{l}\text { Stage of } \\
\text { dementia }\end{array}$ & Type of carer & Main focus & Research method & $\begin{array}{l}\text { Type of } \\
\text { analysis }\end{array}$ \\
\hline 7 & $\begin{array}{l}\text { Chung, } \\
2013\end{array}$ & $\begin{array}{l}\text { not } \\
\text { reported }\end{array}$ & UK & $\begin{array}{l}\text { stage } 1: 15 \text { family } \\
\text { carers; stage } 2: 21 \\
\text { co-resident carers }\end{array}$ & not reported & $\begin{array}{l}\text { stage 1: } 11 \\
\text { female, } 4 \\
\text { male; stage 2: } \\
\text { not reported }\end{array}$ & $\begin{array}{l}\text { not } \\
\text { reported }\end{array}$ & $\mathrm{n} / \mathrm{a}$ & $\begin{array}{l}\text { stage 1: } 12 \\
\text { spouses, } 2 \\
\text { children, } 1 \\
\text { partner; stage 2: } \\
\text { not reported }\end{array}$ & $\begin{array}{l}\text { how carers engage } \\
\text { people with } \\
\text { dementia with } \\
\text { activities }\end{array}$ & $\begin{array}{l}\text { stage 1: interviews; } \\
\text { stage 2: focus } \\
\text { groups }\end{array}$ & $\begin{array}{l}\text { constant } \\
\text { comparison }\end{array}$ \\
\hline 8 & Cott, 2013 & $2005-2007$ & Canada & $\begin{array}{l}20 \text { family members } \\
\& 20 \text { people with } \\
\text { dementia living } \\
\text { alone }\end{array}$ & $\begin{array}{l}\text { People with } \\
\text { dementia: } 67 \text { to } 95 \text {, } \\
\text { Carers: middle- } \\
\text { aged }\end{array}$ & $\begin{array}{l}\text { people with } \\
\text { dementia: } 15 \\
\text { women, } 5 \\
\text { men, carers: } \\
\text { not reported } \\
\text { clearly }\end{array}$ & $\begin{array}{l}\text { not } \\
\text { reported }\end{array}$ & $\begin{array}{l}\text { very mild } \\
\text { to moderate }\end{array}$ & $\begin{array}{l}12 \text { children, } 4 \\
\text { friends, } 1 \text { niece, } 1 \\
\text { nephew, } 1 \text { cousin, } \\
1 \text { sister }\end{array}$ & $\begin{array}{l}\text { how family and } \\
\text { friends balance risk } \\
\text { with people with } \\
\text { dementia who live } \\
\text { alone }\end{array}$ & $\begin{array}{l}\text { in-depth semi- } \\
\text { structured, home / } \\
\text { phone interviews \& } \\
\text { field notes }\end{array}$ & $\begin{array}{l}\text { constant } \\
\text { comparison }\end{array}$ \\
\hline 9 & $\begin{array}{l}\text { de la } \\
\text { Cuesta, } \\
2005\end{array}$ & $2000-2002$ & Colombia & $\begin{array}{l}18 \text { caregivers \& } 2 \\
\text { healthcare } \\
\text { professionals }\end{array}$ & $\begin{array}{l}\text { 10: } 51 \text { to } 75,5: 25 \\
\text { to } 50,3: \text { younger } \\
\text { than } 25\end{array}$ & $\begin{array}{l}15 \text { female, } 3 \\
\text { male }\end{array}$ & Colombian & advanced & $\begin{array}{l}10 \text { daughters, } 5 \text { : } \\
\text { wives, sisters, or } \\
\text { nieces, } 2 \\
\text { husbands, } 1 \text { son. }\end{array}$ & $\begin{array}{l}\text { strategies used by } \\
\text { Colombian family } \\
\text { caregivers to } \\
\text { manage the demands } \\
\text { of care }\end{array}$ & $\begin{array}{l}\text { interviews \& home } \\
\text { observations }\end{array}$ & $\begin{array}{l}\text { constant } \\
\text { comparison }\end{array}$ \\
\hline 10 & $\begin{array}{l}\text { De Witt, } \\
2009\end{array}$ & 2004-2005 & Canada & $\begin{array}{l}8 \text { women with } \\
\text { dementia living } \\
\text { alone }\end{array}$ & 58 to 87 & 8 female & $\begin{array}{l}7 \\
\text { Canadians, } \\
1 \text { not } \\
\text { reported }\end{array}$ & $\begin{array}{l}\text { mild to } \\
\text { moderate }\end{array}$ & $\mathrm{n} / \mathrm{a}$ & $\begin{array}{l}\text { meaning of living } \\
\text { alone for older } \\
\text { people with } \\
\text { dementia }\end{array}$ & $\begin{array}{l}\text { 1:1 open-ended } \\
\text { interviews, journal } \\
\text { notes \& one } \\
\text { participant letter }\end{array}$ & $\begin{array}{l}\text { van } \\
\text { Manen's } \\
\text { method }\end{array}$ \\
\hline
\end{tabular}


Table 2. Continued

\begin{tabular}{|c|c|c|c|c|c|c|c|c|c|c|c|c|}
\hline No & $\begin{array}{l}\text { Study ID } \\
\end{array}$ & $\begin{array}{l}\text { Year study } \\
\text { conducted }\end{array}$ & Country & Participants & Age & Gender & Ethnicity & $\begin{array}{l}\text { Stage of } \\
\text { dementia }\end{array}$ & Type of carer & Main focus & $\begin{array}{l}\text { Research } \\
\text { method }\end{array}$ & $\begin{array}{l}\text { Type of } \\
\text { analysis }\end{array}$ \\
\hline 11 & $\begin{array}{l}\text { Dickson, } \\
2012\end{array}$ & $2011-2012$ & USA & $\begin{array}{l}22 \text { family } \\
\text { carers }\end{array}$ & $\begin{array}{l}50 \text { to } 82 \\
(\mathrm{M}=66)\end{array}$ & not reported & $\begin{array}{l}18 \text { Caucasians, } \\
3 \text { African- } \\
\text { American, } 1 \\
\text { Hispanic }\end{array}$ & all stages & $\begin{array}{l}\text { majority } \\
\text { spouses, then } \\
\text { daughters, } \\
\text { mother, friend }\end{array}$ & $\begin{array}{l}\text { caregivers' } \\
\text { perceptions of } \\
\text { wandering }\end{array}$ & $\begin{array}{l}\text { open-ended, } \\
\text { semi-structured } \\
\text { interviews \& } \\
\text { questionnaire }\end{array}$ & $\begin{array}{l}\text { grounded } \\
\text { theory }\end{array}$ \\
\hline 12 & $\begin{array}{l}\text { Dodds, } \\
1994\end{array}$ & not reported & UK & $\begin{array}{l}6 \text { family } \\
\text { carers }\end{array}$ & $\begin{array}{l}\text { late } 40 \text { s to late } \\
80 \mathrm{~s}\end{array}$ & not reported & not reported & $\begin{array}{l}\text { not } \\
\text { reported }\end{array}$ & $\begin{array}{l}3 \text { spouses, } 2 \\
\text { daughters, } 1 \\
\text { sister; }\end{array}$ & $\begin{array}{l}\text { how carers deal } \\
\text { with wandering } \\
\text { behaviour }\end{array}$ & interviews & not reported \\
\hline 13 & $\begin{array}{l}\text { Drennan, } \\
2011\end{array}$ & not reported & UK & $\begin{array}{l}32 \text { family } \\
\text { carers }\end{array}$ & not reported & $\begin{array}{l}19 \text { female, } \\
13 \text { male }\end{array}$ & $\begin{array}{l}12 \text { White, } 9 \\
\text { other: Afro- } \\
\text { Caribbean, } \\
\text { Asian, } \\
\text { European, } 11 \\
\text { missing }\end{array}$ & $\begin{array}{l}\text { not } \\
\text { reported }\end{array}$ & $\begin{array}{l}21 \text { spouses, } 10 \\
\text { adult child, } 1 \\
\text { daughter-in- } \\
\text { law; }\end{array}$ & $\begin{array}{l}\text { carers' } \\
\text { perceptions of } \\
\text { incontinence } \\
\text { problems and } \\
\text { strategies } \\
\text { employed }\end{array}$ & $\begin{array}{l}\text { face-to-face \& } \\
\text { telephone } \\
\text { interviews }\end{array}$ & $\begin{array}{l}\text { thematic } \\
\text { analysis }\end{array}$ \\
\hline 14 & $\begin{array}{l}\text { Dröes, } \\
2006\end{array}$ & $2002-2003$ & Netherlands & $\begin{array}{l}106 \text { people } \\
\text { with } \\
\text { dementia \& } \\
10 \\
\text { healthcare } \\
\text { professionals }\end{array}$ & $\begin{array}{l}\text { people with } \\
\text { dementia: } 65- \\
80 ; \\
\text { professionals: } \\
34 \text { to } 51\end{array}$ & $\begin{array}{l}\text { People with } \\
\text { dementia: } \\
\text { not } \\
\text { reported; } \\
\text { Professiona } \\
\text { ls: } 9 \text { female, } \\
1 \text { male }\end{array}$ & not reported & $\begin{array}{l}\text { mild to } \\
\text { moderate }\end{array}$ & $\mathrm{n} / \mathrm{a}$ & $\begin{array}{l}\text { what people with } \\
\text { dementia consider } \\
\text { important for their } \\
\text { quality of life }\end{array}$ & $\begin{array}{l}\text { interviews \& } \\
\text { focus groups }\end{array}$ & $\begin{array}{l}\text { constant } \\
\text { comparison }\end{array}$ \\
\hline 15 & $\begin{array}{l}\text { Forbat, } \\
2004\end{array}$ & not reported & UK & $\begin{array}{l}11 \text { family } \\
\text { carers from } \\
\text { BME }\end{array}$ & not reported & not reported & $\begin{array}{l}\text { South-Asian or } \\
\text { Afro- } \\
\text { Caribbean }\end{array}$ & $\mathrm{n} / \mathrm{a}$ & not reported & $\begin{array}{l}\text { difficulties in } \\
\text { continence and } \\
\text { toileting }\end{array}$ & interviews & not reported \\
\hline
\end{tabular}


Table 2. Continued

\begin{tabular}{|c|c|c|c|c|c|c|c|c|c|c|c|c|}
\hline No & Study ID & $\begin{array}{l}\text { Year study } \\
\text { conducted }\end{array}$ & $\begin{array}{l}\text { Countr } \\
y\end{array}$ & Participants & Age & Gender & Ethnicity & $\begin{array}{l}\text { Stage of } \\
\text { dementia }\end{array}$ & Type of carer & Main focus & $\begin{array}{l}\text { Research } \\
\text { method }\end{array}$ & $\begin{array}{l}\text { Type of } \\
\text { analysis }\end{array}$ \\
\hline 16 & $\begin{array}{l}\text { Harris, } \\
2006\end{array}$ & $\begin{array}{l}\text { not } \\
\text { reported }\end{array}$ & USA & $\begin{array}{l}15 \text { people } \\
\text { with dementia } \\
\& 10 \text { family } \\
\text { carers }\end{array}$ & $\begin{array}{l}\text { people with } \\
\text { dementia: } \\
M=75.4 \text { ( } 62 \text { to } \\
\text { 87); Carers: } \\
M=51 \text { ( } 38 \text { to } 60 \text { ) }\end{array}$ & $\begin{array}{l}13 \text { female, } \\
2 \text { males }\end{array}$ & $\begin{array}{l}3 \text { African- } \\
\text { Americans, } \\
12 \text { White }\end{array}$ & $\begin{array}{l}12 \text { early } \\
\text { dementia or } 3 \\
\text { mild MCI }\end{array}$ & $\begin{array}{l}8 \text { children, } 1 \text { cousin, } \\
1 \text { sister }\end{array}$ & $\begin{array}{l}\text { concerns, needs } \\
\text { and coping } \\
\text { strategies of } \\
\text { people with } \\
\text { dementia living } \\
\text { alone }\end{array}$ & $\begin{array}{l}\text { in-depth } \\
\text { interviews }\end{array}$ & $\begin{array}{l}\text { constant } \\
\text { comparison }\end{array}$ \\
\hline 17 & $\begin{array}{l}\text { Hogan, } \\
2003\end{array}$ & $\begin{array}{l}\text { not } \\
\text { reported }\end{array}$ & USA & $\begin{array}{l}8 \text { family } \\
\text { carers }\end{array}$ & 49 to 81 & $\begin{array}{l}2 \text { male, } 6 \\
\text { female }\end{array}$ & $\begin{array}{l}\text { not } \\
\text { reported }\end{array}$ & $\begin{array}{l}\text { early, middle, } \\
\text { late and } \\
\text { unknown }\end{array}$ & $\begin{array}{l}4 \text { spouses, } 3 \text { adult } \\
\text { children, } 1 \text { daughter- } \\
\text { in-law }\end{array}$ & $\begin{array}{l}\text { explore the role } \\
\text { change by family } \\
\text { carers }\end{array}$ & interviews & $\begin{array}{l}\text { thematic } \\
\text { analysis }\end{array}$ \\
\hline 18 & $\begin{array}{l}\text { Kinney, } \\
2004\end{array}$ & 2001 & USA & $\begin{array}{l}26 \text { family } \\
\text { carers }\end{array}$ & $\begin{array}{l}\text { Phase 1: } \\
\mathrm{M}=63.2 \\
(\mathrm{SD}=11.83)\end{array}$ & $\begin{array}{l}\text { Phase 1: } \\
\text { majority } \\
\text { females }\end{array}$ & $\begin{array}{l}\text { Phase 1: } 1 \\
\text { African, } 25 \\
\text { White; }\end{array}$ & $\begin{array}{l}\text { beyond early } \\
\text { stages }\end{array}$ & $\begin{array}{l}\text { one half cared for } \\
\text { parent, step parent } \\
\text { or parent-in-law, } 2 / 5 \\
\text { for a spouse \& rest } \\
\text { for grandparent and } \\
\text { child }\end{array}$ & $\begin{array}{l}\text { challenges in } \\
\text { caregiving and } \\
\text { how technology } \\
\text { assists caregivers }\end{array}$ & focus groups & $\begin{array}{l}\text { Strauss and } \\
\text { Cornin, table } \\
\text { narrative }\end{array}$ \\
\hline 19 & Lach, 2007 & $\begin{array}{l}\text { not } \\
\text { reported }\end{array}$ & USA & $\begin{array}{l}39 \text { co-resident } \\
\text { carers }\end{array}$ & $\begin{array}{l}M=71,6 \\
(S D=10.3)\end{array}$ & $\begin{array}{l}28 \text { women, } \\
11 \text { men }\end{array}$ & $\begin{array}{l}\text { not } \\
\text { reported }\end{array}$ & $\begin{array}{l}\text { very mild, mild } \\
\text { and moderate }\end{array}$ & $\begin{array}{l}34 \text { spouses, } 5 \\
\text { children }\end{array}$ & $\begin{array}{l}\text { experiences of } \\
\text { carers in } \\
\text { managing safety } \\
\text { at home }\end{array}$ & focus groups & $\begin{array}{l}\text { Dilorio } \\
\text { method, } \\
\text { coding book, } \\
\text { contingency } \\
\text { matrix }\end{array}$ \\
\hline 20 & $\begin{array}{l}\text { Nochajski, } \\
2013\end{array}$ & $\begin{array}{l}\text { not } \\
\text { reported }\end{array}$ & USA & $\begin{array}{l}20 \text { people } \\
\text { with } \\
\text { cognitive } \\
\text { impairments } \\
\text { and } 17 \text { carers }\end{array}$ & $\begin{array}{l}\text { people with } \\
\text { dementia: } \mathrm{M}= \\
79 \text {; carers: } 61.8 \text {, } \\
39 \text { to } 80\end{array}$ & $\begin{array}{l}10 \text { female, } \\
10 \text { male }\end{array}$ & $90 \%$ White & not reported & $\begin{array}{l}8 \text { spouses, } 6 \\
\text { children, } 1 \text { sibling, } 1 \\
\text { cousin, } 1 \text { nephew }\end{array}$ & $\begin{array}{l}\text { use and } \\
\text { satisfaction of } \\
\text { assistive devices }\end{array}$ & $\begin{array}{l}\text { questionnaires } \\
\& \text { interviews }\end{array}$ & not reported \\
\hline
\end{tabular}


Table 2. Continued

\begin{tabular}{|c|c|c|c|c|c|c|c|c|c|c|c|c|}
\hline No & Study ID & $\begin{array}{l}\text { Year study } \\
\text { conducted }\end{array}$ & Country & Participants & Age & Gender & Ethnicity & $\begin{array}{l}\text { Stage of } \\
\text { dementia }\end{array}$ & Type of carer & Main focus & $\begin{array}{l}\text { Research } \\
\text { method }\end{array}$ & Type of analysis \\
\hline 21 & $\begin{array}{l}\text { Nygård, } \\
2002\end{array}$ & $\begin{array}{l}\text { not } \\
\text { reported }\end{array}$ & Sweden & $\begin{array}{l}7 \text { people with } \\
\text { dementia }\end{array}$ & 62 to 78 & $\begin{array}{l}4 \text { male, } 3 \\
\text { female }\end{array}$ & $\begin{array}{l}\text { not } \\
\text { reported }\end{array}$ & $\begin{array}{l}\text { mild to } \\
\text { moderate }\end{array}$ & $\mathrm{n} / \mathrm{a}$ & $\begin{array}{l}\text { how people with } \\
\text { dementia manage their } \\
\text { everyday occupations }\end{array}$ & $\begin{array}{l}\text { repeated } \\
\text { interviews, } \\
\text { observations \& } \\
\text { field notes }\end{array}$ & $\begin{array}{l}\text { Empirical } \\
\text { Phenomenological } \\
\text { Psychological } \\
\text { analysis }\end{array}$ \\
\hline 22 & $\begin{array}{l}\text { Nygård, } \\
2003\end{array}$ & $\begin{array}{l}\text { not } \\
\text { reported }\end{array}$ & Sweden & $\begin{array}{l}10 \text { people } \\
\text { with dementia }\end{array}$ & 75 to 87 & $\begin{array}{l}7 \text { female, } \\
3 \text { male }\end{array}$ & $\begin{array}{l}\text { not } \\
\text { reported }\end{array}$ & $\begin{array}{l}\text { mild to } \\
\text { moderate }\end{array}$ & $\mathrm{n} / \mathrm{a}$ & $\begin{array}{l}\text { difficulties and } \\
\text { strategies in telephone } \\
\text { use }\end{array}$ & $\begin{array}{l}\text { interviews, } \\
\text { observations \& } \\
\text { field notes }\end{array}$ & $\begin{array}{l}\text { constant } \\
\text { comparison }\end{array}$ \\
\hline 23 & $\begin{array}{l}\text { Nygård, } \\
2008\end{array}$ & $\begin{array}{l}\text { not } \\
\text { reported }\end{array}$ & Sweden & $\begin{array}{l}8 \text { people with } \\
\text { dementia }\end{array}$ & 57 to 82 & $\begin{array}{l}3 \text { male, } 5 \\
\text { female }\end{array}$ & $\begin{array}{l}\text { not } \\
\text { reported }\end{array}$ & $\begin{array}{l}\text { mild to } \\
\text { moderate }\end{array}$ & $\mathrm{n} / \mathrm{a}$ & $\begin{array}{l}\text { how people with } \\
\text { dementia experience } \\
\text { and use everyday } \\
\text { technology }\end{array}$ & $\begin{array}{l}\text { repeated } \\
\text { interviews \& } \\
\text { observations }\end{array}$ & $\begin{array}{l}\text { Empirical } \\
\text { Phenomenological } \\
\text { Psychological } \\
\text { analysis }\end{array}$ \\
\hline 24 & $\begin{array}{l}\text { O'Donnell, } \\
2000\end{array}$ & $\begin{array}{l}\text { not } \\
\text { reported }\end{array}$ & USA & $\begin{array}{l}12 \text { spousal } \\
\text { carers }\end{array}$ & $\begin{array}{l}\text { Carers: } 49 \text { to } \\
78 \text { (M=68); } \\
\text { People with } \\
\text { dementia: } 60- \\
96(\mathrm{M}=73)\end{array}$ & $\begin{array}{l}10 \text { female, } \\
2 \text { male }\end{array}$ & $\begin{array}{l}11 \\
\text { Caucasian, } \\
1 \text { Black }\end{array}$ & $\begin{array}{l}\text { pass very } \\
\text { mild stage }\end{array}$ & all spouses & $\begin{array}{l}\text { experience of spouse } \\
\text { carers of their day-to- } \\
\text { day life }\end{array}$ & $\begin{array}{l}\text { interviews, } \\
\text { observations \& } \\
\text { field notes }\end{array}$ & Colaizzi's method \\
\hline 25 & Olsen, 1996 & $\begin{array}{l}\text { not } \\
\text { reported }\end{array}$ & USA & $\begin{array}{l}90 \text { family } \\
\text { carers of } \\
\text { people with } \\
\text { dementia }\end{array}$ & not reported & $\begin{array}{l}60 \text { female, } \\
30 \text { male }\end{array}$ & $\begin{array}{l}\text { not } \\
\text { reported }\end{array}$ & $\begin{array}{l}\text { not } \\
\text { reported }\end{array}$ & $\begin{array}{l}46 \text { spouses, } 41 \\
\text { children, } 3 \\
\text { other }\end{array}$ & $\begin{array}{l}\text { impact of physical } \\
\text { environment and } \\
\text { strategies used }\end{array}$ & $\begin{array}{l}\text { in-depth home } \\
\text { interviews \& } \\
\text { scales }\end{array}$ & not reported \\
\hline 26 & $\begin{array}{l}\text { Olsson, } \\
1998\end{array}$ & $\begin{array}{l}\text { not } \\
\text { reported }\end{array}$ & Sweden & $\begin{array}{l}36 \text { home care } \\
\text { staff }\end{array}$ & not reported & $\begin{array}{l}1 \text { male, } 34 \\
\text { female }\end{array}$ & $\begin{array}{l}\text { not } \\
\text { reported }\end{array}$ & $\begin{array}{l}\text { not } \\
\text { reported }\end{array}$ & $\mathrm{n} / \mathrm{a}$ & $\begin{array}{l}\text { staff's reflections on } \\
\text { caring for people with } \\
\text { dementia }\end{array}$ & interviews & $\begin{array}{l}\text { constant } \\
\text { comparison }\end{array}$ \\
\hline
\end{tabular}


Table 2. Continued

\begin{tabular}{|c|c|c|c|c|c|c|c|c|c|c|c|c|}
\hline No & Study ID & $\begin{array}{l}\text { Year study } \\
\text { conducted }\end{array}$ & Country & Participants & Age & Gender & Ethnicity & $\begin{array}{l}\text { Stage of } \\
\text { dementia }\end{array}$ & Type of carer & Main focus & Research method & $\begin{array}{l}\text { Type of } \\
\text { analysis }\end{array}$ \\
\hline 27 & $\begin{array}{l}\text { Olsson, } \\
2011\end{array}$ & $2007-2008$ & Sweden & $\begin{array}{l}14 \text { spousal } \\
\text { carers }\end{array}$ & 62 to 89 & 8 female, 6 male & $\begin{array}{l}\text { not } \\
\text { reported }\end{array}$ & $\begin{array}{l}\text { mean time of } \\
\text { diagnosis: } 6 \\
\text { years }\end{array}$ & all spouses & $\begin{array}{l}\text { reflections of } \\
\text { family carers } \\
\text { on use of ICT }\end{array}$ & $\begin{array}{l}\text { individual } \\
\text { interviews }\end{array}$ & $\begin{array}{l}\text { content } \\
\text { analysis }\end{array}$ \\
\hline 28 & $\begin{array}{l}\text { Powell, } \\
2010\end{array}$ & $\begin{array}{l}\text { not } \\
\text { reported }\end{array}$ & UK & $\begin{array}{l}34 \text { informal } \\
\text { carers }\end{array}$ & 23 to $91(\mathrm{M}=57)$ & $\begin{array}{l}12 \text { male, } 22 \\
\text { female }\end{array}$ & $\begin{array}{l}27 \text { White } \\
\text { British, } 7 \\
\text { other }\end{array}$ & $\begin{array}{l}\text { different } \\
\text { stages, some } \\
\text { with early- } \\
\text { onset } \\
\text { dementia }\end{array}$ & $\begin{array}{l}15 \text { spouses, } 15 \text { adult } \\
\text { children, } 3 \\
\text { grandchildren, } 1 \\
\text { friend }\end{array}$ & $\begin{array}{l}\text { carers' } \\
\text { perceptions on } \\
\text { networked ICT }\end{array}$ & $\begin{array}{l}\text { semi-structured } \\
\text { interviews \& } \\
\text { group discussion }\end{array}$ & $\begin{array}{l}\text { framework } \\
\text { approach }\end{array}$ \\
\hline 29 & $\begin{array}{l}\text { Redfern, } \\
2002\end{array}$ & $\begin{array}{l}\text { not } \\
\text { reported }\end{array}$ & UK & $\begin{array}{l}20 \text { couples } \\
\text { of people } \\
\text { with } \\
\text { dementia } \\
\text { and their } \\
\text { carers }\end{array}$ & $\begin{array}{l}\text { people with } \\
\text { dementia: } \\
M=85 \text {, spouses: } \\
M=79 \text {, children: } \\
M=50\end{array}$ & $\begin{array}{l}\text { people with } \\
\text { dementia: } 15 \\
\text { female, } 5 \text { male; } \\
\text { carers: } 14 \text { female, } \\
6 \text { male }\end{array}$ & $\begin{array}{l}\text { not } \\
\text { reported }\end{array}$ & $\begin{array}{l}\text { moderate to } \\
\text { severe }\end{array}$ & $\begin{array}{l}7 \text { children, } 9 \\
\text { spouses, } 4 \text { unrelated }\end{array}$ & $\begin{array}{l}\text { care at home } \\
\text { focusing on } \\
\text { routines, } \\
\text { control and } \\
\text { care goals }\end{array}$ & $\begin{array}{l}\text { repeated home } \\
\text { interviews \& } \\
\text { observation }\end{array}$ & $\begin{array}{l}\text { content } \\
\text { analysis, } \\
\text { constant } \\
\text { compariso } \\
\text { n }\end{array}$ \\
\hline 30 & $\begin{array}{l}\text { Richter, } \\
1995\end{array}$ & $\begin{array}{l}\text { not } \\
\text { reported }\end{array}$ & USA & $\begin{array}{l}23 \text { family } \\
\text { carers \& } 22 \\
\text { paid carers }\end{array}$ & $\begin{array}{l}\text { former carers: } \\
\text { not reported; } \\
\text { paid carers: } \\
\mathrm{M}=24\end{array}$ & majority females & $\begin{array}{l}\text { all } \\
\text { Caucasian }\end{array}$ & not reported & $\begin{array}{l}\text { either spouses or } \\
\text { adult children }\end{array}$ & $\begin{array}{l}\text { communicative } \\
\text { processes used } \\
\text { by family and } \\
\text { paid carers }\end{array}$ & focus groups & $\begin{array}{l}\text { three-phase } \\
\text { analysis }\end{array}$ \\
\hline 31 & $\begin{array}{l}\text { Rosenberg, } \\
2012\end{array}$ & $\begin{array}{l}\text { not } \\
\text { reported }\end{array}$ & Sweden & $\begin{array}{l}16 \text { informal } \\
\text { carers }\end{array}$ & 45 to 78 & 11 female, 5 male & $\begin{array}{l}\text { not } \\
\text { reported }\end{array}$ & not reported & $\begin{array}{l}5 \text { children, } 1 \\
\text { neighbour, } 9 \text { spouses, } \\
1 \text { son-in-law }\end{array}$ & $\begin{array}{l}\text { attitudes to } \\
\text { technologies }\end{array}$ & $\begin{array}{l}\text { interviews \& } \\
\text { focus groups }\end{array}$ & $\begin{array}{l}\text { constant } \\
\text { compariso } \\
\mathrm{n}\end{array}$ \\
\hline 32 & $\begin{array}{l}\text { Sixsmith, } \\
2007\end{array}$ & $\begin{array}{l}\text { not } \\
\text { reported }\end{array}$ & UK & $\begin{array}{l}26 \text { people } \\
\text { with } \\
\text { dementia } \\
\text { and their } \\
\text { carers }\end{array}$ & 62 to 96 & 18 female, 8 male & $\begin{array}{l}\text { not } \\
\text { reported }\end{array}$ & not reported & not reported & $\begin{array}{l}\text { meaning and } \\
\text { role of music }\end{array}$ & $\begin{array}{l}\text { in-depth } \\
\text { interviews (some } \\
\text { repeated) }\end{array}$ & $\begin{array}{l}\text { thematic } \\
\text { analysis }\end{array}$ \\
\hline
\end{tabular}


Table 2. Continued

\begin{tabular}{|c|c|c|c|c|c|c|c|c|c|c|c|c|}
\hline No & $\begin{array}{l}\text { Study } \\
\text { ID }\end{array}$ & Year & Country & Participants & Age & Gender & Ethnicity & $\begin{array}{l}\text { Stage of } \\
\text { dementia }\end{array}$ & Type of carer & Main focus & Research method & $\begin{array}{l}\text { Type of } \\
\text { analysis }\end{array}$ \\
\hline 33 & $\begin{array}{l}\text { Smith, } \\
2001\end{array}$ & $\begin{array}{l}\text { not } \\
\text { reported }\end{array}$ & USA & 45 family carers & 36-75 or older & $\begin{array}{l}39 \text { female, } 6 \\
\text { male }\end{array}$ & not reported & $\begin{array}{l}\text { mild to } \\
\text { severe }\end{array}$ & $\begin{array}{l}23 \text { spouses, } 16 \\
\text { adult children }\end{array}$ & $\begin{array}{l}\text { different types of } \\
\text { needs for carers }\end{array}$ & $\begin{array}{l}\text { semi-structured } \\
\text { intensive } \\
\text { interviews }\end{array}$ & not reported \\
\hline 34 & $\begin{array}{l}\text { Spring, } \\
2009\end{array}$ & $\begin{array}{l}\text { not } \\
\text { reported }\end{array}$ & USA & 14 family carers & 38 to $86(M=64)$ & $\begin{array}{l}13 \text { female, } 1 \\
\text { male }\end{array}$ & $\begin{array}{l}11 \text { White, } 2 \\
\text { African- } \\
\text { American, } 1 \\
\text { Hispanic }\end{array}$ & $\begin{array}{l}\text { not } \\
\text { reported }\end{array}$ & $\begin{array}{l}8 \text { spouses, } 5 \\
\text { daughters, } 1 \\
\text { grand-daughter; }\end{array}$ & $\begin{array}{l}\text { problems } \\
\text { associated with } \\
\text { night time } \\
\text { supervision }\end{array}$ & $\begin{array}{l}\text { semi-structured } \\
\text { home interviews }\end{array}$ & $\begin{array}{l}\text { grounded } \\
\text { theory }\end{array}$ \\
\hline 35 & $\begin{array}{l}\text { Taşcı, } \\
2012\end{array}$ & $\begin{array}{l}\text { not } \\
\text { reported }\end{array}$ & Turkey & 8 family carers & $M=48,87$ & not reported & not reported & $\begin{array}{l}\text { not } \\
\text { reported }\end{array}$ & $\begin{array}{l}3 \text { spouses, } 4 \\
\text { adult children, } \\
1 \text { daughter-in- } \\
\text { law }\end{array}$ & $\begin{array}{l}\text { problems } \\
\text { experienced by } \\
\text { family Turkish } \\
\text { carers }\end{array}$ & $\begin{array}{l}\text { focus groups \& } \\
\text { questionnaires }\end{array}$ & not reported \\
\hline 36 & $\begin{array}{l}\text { Toot, } \\
2013\end{array}$ & $\begin{array}{l}\text { not } \\
\text { reported }\end{array}$ & UK & $\begin{array}{l}18 \text { people with } \\
\text { dementia, } 15 \text { family } \\
\text { carers, } 19 \text { healthcare } \\
\text { professionals }\end{array}$ & $\begin{array}{l}\text { people with } \\
\text { dementia: } \\
.>65 \mathrm{yrs:1} \\
<65: 17 \text {; carers: } 6 \\
>65 \mathrm{yrs}, 9>65 \mathrm{yrs} ; \\
\text { Professionals: not } \\
\text { reported }\end{array}$ & $\begin{array}{l}\text { people with } \\
\text { dementia: } 10 \\
\text { females } 8 \text { male; } \\
\text { carers: } 6 \text { male, } 9 \\
\text { female; Profs: } \\
11 \text { female, } 8 \\
\text { male }\end{array}$ & $\begin{array}{l}\text { people with } \\
\text { dementia \& } \\
\text { Professionals: } \\
\text { not reported; } \\
\text { carers: range } \\
\text { of ethnicities }\end{array}$ & $\begin{array}{l}\text { mild- } \\
\text { moderate } \\
\text { stage }\end{array}$ & $\begin{array}{l}9 \text { spouses, } 5 \\
\text { child, } 1 \text { friend, } \\
\text { staff: } 11 \\
\text { females, } 8 \\
\text { males }\end{array}$ & $\begin{array}{l}\text { factors } \\
\text { precipitating } \\
\text { crises and } \\
\text { interventions used } \\
\text { in dementia care }\end{array}$ & focus groups & $\begin{array}{l}\text { thematic and } \\
\text { long-table } \\
\text { approach }\end{array}$ \\
\hline
\end{tabular}


Table 2. Continued

\begin{tabular}{|c|c|c|c|c|c|c|c|c|c|c|c|c|}
\hline No & Study ID & $\begin{array}{l}\text { Year study } \\
\text { conducted }\end{array}$ & Country & Participants & Age & Gender & $\begin{array}{l}\text { Ethnicit } \\
\mathrm{y}\end{array}$ & $\begin{array}{l}\text { Stage of } \\
\text { dementia }\end{array}$ & $\begin{array}{l}\text { Type of } \\
\text { carer }\end{array}$ & Main focus & $\begin{array}{l}\text { Research } \\
\text { method }\end{array}$ & $\begin{array}{l}\text { Type of } \\
\text { analysis }\end{array}$ \\
\hline 37 & $\begin{array}{l}\text { Van Hoof, } \\
2009\end{array}$ & $\begin{array}{l}\text { sample 1: } \\
\text { not } \\
\text { reported; } \\
\text { sample 2: } \\
\text { 2006-2007 }\end{array}$ & Netherlands & $\begin{array}{l}\text { sample 1:10 carers } \\
\text { and people with } \\
\text { dementia; sample 2: } \\
18 \text { older people } \\
\text { (some with } \\
\text { dementia) }\end{array}$ & $\begin{array}{l}\text { sample 2: } \\
63-87 \mathrm{yrs}\end{array}$ & $\begin{array}{l}\text { sample 1: carers: } \\
2 \text { male, } 8 \text { female; } \\
\text { people with } \\
\text { dementia: } 4 \text { male, } \\
6 \text { female/ sample } \\
2: 14 \text { female, } 4 \\
\text { male }\end{array}$ & $\begin{array}{l}\text { not } \\
\text { reported }\end{array}$ & not reported & $\begin{array}{l}\text { sample 1: } \\
\text { often } \\
\text { relatives / } \\
\text { sample 2: } \\
\text { n/a }\end{array}$ & $\begin{array}{l}\text { experiences of } \\
\text { technology at home } \\
\text { and thermal } \\
\text { environment }\end{array}$ & $\begin{array}{l}\text { interviews \& } \\
\text { questionnaires }\end{array}$ & $\begin{array}{l}\text { theoretical } \\
\text { framework }\end{array}$ \\
\hline 38 & $\begin{array}{l}\text { Vikström, } \\
2005\end{array}$ & $\begin{array}{l}\text { not } \\
\text { reported }\end{array}$ & Sweden & $\begin{array}{l}30 \text { co-habiting } \\
\text { couples of people } \\
\text { with dementia and } \\
\text { their carers }\end{array}$ & $\begin{array}{l}\text { carers: } 58 \\
\text { to } 84 \\
(\mathrm{M}=74) \text {; } \\
\text { people with } \\
\text { dementia: } \\
68 \text { to } 85 \\
(\mathrm{M}=78)\end{array}$ & $\begin{array}{l}\text { carers: } 14 \text { male, } \\
16 \text { female; people } \\
\text { with dementia: } 16 \\
\text { male, } 14 \text { female }\end{array}$ & $\begin{array}{l}\text { not } \\
\text { reported }\end{array}$ & $\begin{array}{l}\text { mild to } \\
\text { moderate }\end{array}$ & 30 spouses & $\begin{array}{l}\text { family carers' self- } \\
\text { initiated support to } \\
\text { partners with } \\
\text { dementia }\end{array}$ & $\begin{array}{l}\text { video recording, } \\
\text { observation \& } \\
\text { field notes }\end{array}$ & $\begin{array}{l}\text { constant } \\
\text { comparison }\end{array}$ \\
\hline 39 & $\begin{array}{l}\text { Wherton, } \\
2008\end{array}$ & $\begin{array}{l}\text { not } \\
\text { reported }\end{array}$ & UK & $\begin{array}{l}\text { study 1: } 20 \\
\text { healthcare } \\
\text { professionals; study } \\
\text { 2: } 10 \text { family carers } \\
\text { and } 8 \text { people with } \\
\text { dementia }\end{array}$ & $\begin{array}{l}\text { not } \\
\text { reported }\end{array}$ & not reported & $\begin{array}{l}\text { not } \\
\text { reported }\end{array}$ & $\begin{array}{l}\text { mild to } \\
\text { moderate }\end{array}$ & $\begin{array}{l}\text { not } \\
\text { reported }\end{array}$ & $\begin{array}{l}\text { difficulties and } \\
\text { opportunities for } \\
\text { technological } \\
\text { solutions }\end{array}$ & $\begin{array}{l}\text { interviews \& } \\
\text { focus group }\end{array}$ & $\begin{array}{l}\text { grounded } \\
\text { approach }\end{array}$ \\
\hline 40 & Yang, 1997 & $\begin{array}{l}\text { not } \\
\text { reported }\end{array}$ & USA & $\begin{array}{l}7 \text { people with } \\
\text { dementia } 8 \text { family } \\
\text { carers, } 1 \text { paid carer }\end{array}$ & $\begin{array}{l}\text { people with } \\
\text { dementia: } \\
72 \text { to } 92 \\
(\mathrm{M}=81.6) ; \\
\text { carers: } 47 \text { to } \\
80(\mathrm{M}=62)\end{array}$ & $\begin{array}{l}\text { people with } \\
\text { dementia: } 3 \text { male, } \\
4 \text { female; carers: } 6 \\
\text { female, } 2 \text { male }\end{array}$ & $\begin{array}{l}6 \text { White } \\
\text { Caucasi } \\
\text { an, } 1 \\
\text { African- } \\
\text { America } \\
\mathrm{n}\end{array}$ & $\begin{array}{l}\text { MMSE: 10- } \\
23\end{array}$ & $\begin{array}{l}3 \text { spouses, } \\
\text { four } \\
\text { children, } 1 \\
\text { nephew }\end{array}$ & $\begin{array}{l}\text { perceptions on the } \\
\text { use of assistive } \\
\text { devices }\end{array}$ & $\begin{array}{l}\text { open-ended } \\
\text { questionnaire }\end{array}$ & $\begin{array}{l}\text { descriptive } \\
\text { analysis }\end{array}$ \\
\hline
\end{tabular}


Table 3. Critical Appraisal Skills Programme (CASP) Checklist

\begin{tabular}{ll}
\hline Questions & Domains \\
Q1. & Was there a clear statement of the aims of the research? \\
Q2. & Is a qualitative methodology appropriate? \\
Q3. & Was the research design appropriate to address the aims of the research? \\
Q4. & Was the recruitment strategy appropriate to the aims of the research? \\
Q5. & Hans the relationship between researcher and participants been adequately \\
Q6. & Have ethical issues been taken into consideration? \\
Q7. & How the data analysis sufficiently rigorous? \\
Q8. & \\
Q9. & How allear statement of findings? \\
Q10. &
\end{tabular}


Table 4. References of Included Papers $(N=42)$

1. Aminzadeh, F., Dalziel, W. B., Molnar, F. J., \& Garcia, L. J. (2010). Meanings, functions, and experiences of living at home for individuals with dementia at the critical point of relocation. Journal of Gerontological Nursing, 36(6), 28-35. doi:10.3928/0098913420100303-02

2. Askham, J., Briggs, K., Norman, I., \& Redfern, S. (2007). Care at home for people with dementia: as in a total institution? Ageing and Society, 27(01), 3-24. doi:10.1017/S0144686X06005307

3. Baker, F. A., Grocke, D., \& Pachana, N. A. (2012). Connecting through music: A study of a spousal caregiver-directed music intervention designed to prolong fulfilling relationships in couples where one person has dementia. Australian Journal of Music Therapy, 23, 4-19.

4. Boger, J., Quraishi, M., Turcotte, N., \& Dunal, L. (2013). The identification of assistive technologies being used to support the daily occupations of community-dwelling older adults with dementia: a cross-sectional pilot study. Disability \& Rehabilitation: Assistive Technology, 9(1), 17-30. doi:10.3109/17483107.2013.785035

5. Buri, H., \& Dawson, P. (2000). Caring for a relative with dementia: A theoretical model of coping with fall risk. Health, Risk \& Society, 2(3), 283-293. doi: http://dx.doi.org/10.1080/713670166

6. Chung, J. C.-C. (1997). Focus on family care givers for individuals with dementia: Implications for occupational therapy practice. Occupational Therapy International, 4(1), 66-80. doi: 10.1002/oti.48

7. Chung, P. (2013). Professionals partnering with family carers in home-based activity for those with dementia. WFOT Bulletin, 67(May), 9-16. doi: http://dx.doi.org/10.1179/otb.2013.67.1.003

8. Cott, C. A., \& Tierney, M. C. (2013). Acceptable and unacceptable risk: balancing everyday risk by family members of older cognitively impaired adults who live alone. Health Risk \& Society, 15(5, SI), 402-415. doi:10.1080/13698575.2013.801936

9. de la Cuesta, C. (2005). The craft of care: family care of relatives with advanced dementia. Qualitative Health Research, 15(7), 881-96. doi:10.1177/1049732305277805

10. de la Cuesta, C., \& Sandelowski, M. (2005). Tenerlos en la casa: The material world and craft of family caregiving for relatives with dementia. Journal of Transcultural Nursing, 16(3), 218-225. doi:10.1177/1043659605274979 
Table 4. Continued

11. De Witt, L., Ploeg, J., \& Black, M. (2009). Living on the threshold: The spatial experience of living alone with dementia. Dementia, 8(2), 263-291. doi:10.1177/1471301209103273

12. Dickson, P. (2012). Caregiver perceptions of wandering behavior in the ADRD (Alzheimer's Disease and Related Dementias) patient (Doctoral dissertation). Retrieved from http://digital.library.unt.edu/ark:/67531/metadc149582/.

13. Dodds, P. (1994). Wandering: a short report on coping strategies adopted by informal carers. International Journal of Geriatric Psychiatry, 9(9), 751-756. doi:10.1002/gps.930090910

14. Drennan, V. M., Cole, L., \& Iliffe, S. (2011). A taboo within a stigma? a qualitative study of managing incontinence with people with dementia living at home. BMC Geriatrics, 11, 75. doi: 10.1186/1471-2318-11-75.

15. Dröes, R.-M., Boelens-Van der Knoop, E. C., Bos, J., Meihuizen, L., Ettema, T. P., Gerritsen, D. L., ... Schölzel-Dorenbos, C. J. M. (2006). Quality of life in dementia in perspective. An explorative study of variations in opinions among people with dementia and their professional caregivers, and in literature. Dementia, 5(4), 533-558. doi:10.1177/1471301206069929

16. Forbat, L. (2004). Listening to carers talking about the subjects of continence and toileting. Nursing Times, 100(2), 46-49.

17. Harris, P. B. (2006). The experience of living alone with early stage Alzheimer's disease: what are the person's concerns? Alzheimer's Care Quarterly, 7(2), 84-94.

18. Hogan, V. M., Lisy, E. D., Savannah, R. L., Henry, L., Kuo, F., \& Fisher, G. S. (2003). Role change experienced by family caregivers of adults with Alzheimer's Disease: Implications for occupational therapy. Physical \& Occupational Therapy in Geriatrics, 22(1), 21-43. doi:10.1300/J148v22n01_02

19. Kinney, J. M., Kart, C. S., Murdoch, L. D., \& Ziemba, T. F. (2003). Challenges in caregiving and creative solutions: Using technology to facilitate caring for a relative with dementia. Ageing International, 28(3), 295-314. doi:10.1007/s12126-002-1009-x

20. Lach, H. W., \& Chang, Y.-P. (2007). Caregiver perspectives on safety in home dementia care. Western Journal of Nursing Research, 29(8), 993-1014. 
Table 4. Continued

21. Nochajski, S. M., Tomita, M. R., \& Mann, W. C. (1996). The use and satisfaction with assistive devices by older persons with cognitive impairments: a pilot intervention study. Topics in Geriatric Rehabilitation, 12(2), 40-53.

22. Nygård, L. (2008). The meaning of everyday technology as experienced by people with dementia who live alone. Dementia, 7(4), 481502. doi: $10.1177 / 1471301208096631$

23. Nygård, L., \& Öhman, A. (2002). Managing changes in everyday occupations: the experience of persons with Alzheimer's disease. OTJR: Occupation, Participation \& Health, 22(2), 70-81.

24. Nygård, L., \& Starkhammar, S. (2003). Telephone use among noninstitutionalized persons with dementia living alone: mapping out difficulties and response strategies. Scandinavian Journal of Caring Sciences, 17(3), 239-249.

25. O'Donnell, M. E. (2000). The long grey tunnel: the day-to-day experience of spouse caregivers of people with Alzheimer's disease. Scholarly Inquiry for Nursing Practice, 14(1), 47-71.

26. Olsen, R. V, Ehrenkrantz, E., \& Hutchings, B. L. (1996). Creating the movement-access continuum in home environments for dementia care. Topics in Geriatric Rehabilitation, 12(2), 1-8.

27. Olsen, R. V, Hutchings, B. L., \& Ehrenkrantz, E. (1999). The physical design of the home as a caregiving support: an environment for persons with dementia. Care Management Journals: Journal of Case Management; The Journal of Long Term Home Health Care, 1(2), $125-131$.

28. Olsson, A., Engström, M., Skovdahl, K., \& Lampic, C. (2011). My, your and our needs for safety and security: relatives' reflections on using information and communication technology in dementia care. Scandinavian Journal of Caring Sciences, 26(1), $104-112$. doi:10.1111/j.1471-6712.2011.00916.x

29. Olsson, A., \& Hallberg, I. R. (1998). Caring for demented people in their homes or in sheltered accommodation as reflected on by homecare staff during clinical supervision sessions. Journal of Advanced Nursing, 27(2), 241-252. doi:10.1046/j.1365-2648.1998.00515.x

30. Powell, J., Gunn, L., Lowe, P., Sheehan, B., Griffiths, F., \& Clarke, A. (2010). New networked technologies and carers of people with dementia: an interview study. Ageing \& Society, 30, 1073-1088. doi:http://dx.doi.org/10.1017/S0144686X1000019X 
Table 4. Continued

31. Redfern, S., Norman, I., Briggs, K., \& Askham, J. (2002). Care at home for people with dementia: routines, control and care goals. Quality in Ageing, 3(4), 12-23. doi: http://dx.doi.org/10.1108/14717794200200023

32. Richter, J. M., Roberto, K. A., \& Bottenberg, D. J. (1995). Communicating with persons with Alzheimer's disease: experiences of family and formal caregivers. Archives of Psychiatric Nursing, 9(5), 279-85.

33. Rosenberg, L., Kottorp, a., \& Nygard, L. (2012). Readiness for technology use with people with dementia: The perspectives of significant others. Journal of Applied Gerontology, 31(4), 510-530. doi:10.1177/0733464810396873

34. Sixsmith, A., \& Gibson, G. (2007). Music and the wellbeing of people with dementia. Ageing \& Society, 27(1), 127-145. doi:http://dx.doi.org/10.1017/S0144686X06005228

35. Smith, A. L. (2001). Caregiver needs. Clinical Gerontologist, 24(1-2), 3 - 26. doi:10.1300/J018v24n01

36. Spring, H. J., Rowe, M. A., \& Kelly, A. (2009). Improving caregivers' well-being by using technology to assist in managing nighttime activity in persons with dementia. Research in Gerontological Nursing, 2(1), 39-48. doi:10.3928/19404921-20090101-10

37. Taşc1, S., Kartın, P. T., Ceyhan, Ö., Sungur, G., \& Göriş, S. (2012). Living with an Alzheimer patient in Turkey. Journal of Neuroscience Nursing, 44(4), 228-234. doi: 10.1097/JNN.0b013e3182527627.

38. Toot, S., Hoe, J., Ledgerd, R., Burnell, K., Devine, M., \& Orrell, M. (2013). Causes of crises and appropriate interventions : The views of people with dementia , carers and healthcare professionals. Aging \& Mental Health, 17(3), 328-335. doi:10.1080/13607863.2012.732037

39. van Hoof, J., Kort, H. S. M., Hensen, J. L. M., Duijnstee, M. S. H., \& Rutten, P. G. S. (2010). Thermal comfort and the integrated design of homes for older people with dementia. Building and Environment, 45(2), 358-370. doi:10.1016/j.buildenv.2009.06.013

40. Vikström, S., Borell, L., Stigsdotter-neely, A., \& Josephsson, S. (2005). Caregivers' self-initiated support toward their partners with dementia when performing an everyday occupation together at home. OTJR: Occupation, Participation \& Health, 25(34), 1-11.

41. Wherton, J. P., \& Monk, A. F. (2008). Technological opportunities for supporting people with dementia who are living at home. International Journal of Human-Computer Studies, 66(8), 571-586. doi:10.1016/j.ijhcs.2008.03.001

42. Yang, J. J., Mann, W. C., Nochajski, S., \& Tomita, M. R. (1997). Use of assistive devices among elders with cognitive impairment: A follow-up study. Topics in Geriatric Rehabilitation, 13(2), 13-31. 
Table 5. Quality Assessment of Included Studies (N=40)

\begin{tabular}{|c|c|c|c|c|c|c|c|c|c|c|c|}
\hline $\begin{array}{l}\mathrm{N} \\
\mathrm{o}\end{array}$ & Study ID & Q1. aims & $\begin{array}{l}\text { Q2. research } \\
\text { methods }\end{array}$ & $\begin{array}{l}\text { Q3. research } \\
\text { design }\end{array}$ & $\begin{array}{l}\text { Q4. recruitment } \\
\text { strategy }\end{array}$ & Q5. data collection & Q6. reflexivity & $\begin{array}{l}\text { Q7. ethical } \\
\text { issues }\end{array}$ & Q8. analysis & Q9. findings & $\begin{array}{l}\text { Q10. valuable } \\
\text { research }\end{array}$ \\
\hline 1 & Aminzadeh, 2010 & + & + & + & + & + & - & + & + & + & + \\
\hline 2 & Askham, 2007 & + & + & + & + & + & + & + & - & + & + \\
\hline 3 & Baker, 2012 & + & + & + & + & + & - & + & + & + & + \\
\hline 4 & Boger, 2013 & + & + & + & + & + & - & + & - & + & + \\
\hline 5 & Buri, 2000 & + & + & + & + & + & + & + & + & + & + \\
\hline 6 & Chung, 1997 & + & + & + & + & + & - & + & + & + & + \\
\hline 7 & Chung, 2013 & + & + & + & + & + & - & + & - & + & + \\
\hline 8 & Cott, 2013 & + & + & + & + & + & - & + & + & + & + \\
\hline 9 & de la Cuesta, 2005 & + & + & + & + & + & - & + & + & + & + \\
\hline 10 & De Witt, 2009 & + & + & + & + & + & + & + & + & + & + \\
\hline 11 & Dickson, 2012 & + & + & + & + & + & + & + & + & + & + \\
\hline 12 & Dodds, 1994 & + & + & + & + & + & - & - & - & + & + \\
\hline 13 & Drennan, 2011 & + & + & + & + & + & - & + & + & + & + \\
\hline 14 & Dröes, 2006 & + & + & + & + & + & - & - & - & + & + \\
\hline 15 & Forbat, 2003 & + & + & + & + & + & - & - & - & + & + \\
\hline 16 & Harris, 2006 & + & + & + & + & + & - & + & + & + & + \\
\hline 17 & Hogan, 2003 & + & + & + & + & + & - & + & + & + & + \\
\hline 18 & Kinney, 2003 & + & + & + & + & + & - & + & - & + & + \\
\hline 19 & Lach, 2007 & + & + & + & + & + & - & + & + & + & + \\
\hline 20 & Nochajski, 2013 & + & + & + & + & + & - & - & - & + & + \\
\hline 21 & Nygård, 2002 & + & + & + & + & + & - & - & + & + & + \\
\hline
\end{tabular}


Table 5. Continued

\begin{tabular}{|c|c|c|c|c|c|c|c|c|c|c|c|}
\hline $\begin{array}{l}\mathrm{N} \\
\mathrm{o}\end{array}$ & Study ID & Q1. aims & $\begin{array}{l}\text { Q2. research } \\
\text { methods }\end{array}$ & $\begin{array}{l}\text { Q3. research } \\
\text { design }\end{array}$ & $\begin{array}{l}\text { Q4. recruitment } \\
\text { strategy }\end{array}$ & Q5. data collection & Q6. reflexivity & $\begin{array}{l}\text { Q7. ethical } \\
\text { issues }\end{array}$ & Q8. analysis & Q9. findings & $\begin{array}{l}\text { Q10. valuable } \\
\text { research }\end{array}$ \\
\hline 22 & Nygård, 2003 & + & + & + & + & + & + & - & + & + & + \\
\hline 23 & Nygård, 2008 & + & + & + & + & + & - & - & + & + & + \\
\hline 24 & O'Donnell, 2000. & + & + & + & + & + & - & + & + & + & + \\
\hline 25 & Olsen, 1996 & + & + & + & + & + & - & - & - & + & + \\
\hline 26 & Olsson, 1998 & + & + & + & + & + & - & - & + & + & + \\
\hline 27 & Olsson, 2011 & + & + & + & + & + & - & + & + & + & + \\
\hline 28 & Powell, 2010 & + & + & + & + & + & - & + & + & + & + \\
\hline 29 & Redfern, 2002 & + & + & + & + & + & - & + & + & + & + \\
\hline 30 & Richter, 1995 & + & + & + & + & + & - & - & + & + & + \\
\hline 31 & Rosenberg, 2012 & + & + & + & + & + & - & + & + & + & + \\
\hline 32 & Sixsmith, 2007 & + & + & + & + & + & - & + & - & + & + \\
\hline 33 & Smith, 2001 & + & + & + & + & + & - & + & - & + & + \\
\hline 34 & Spring, 2009 & + & + & + & + & + & - & - & + & + & + \\
\hline 35 & Taşc1, 2012 & + & + & + & + & + & - & + & - & + & + \\
\hline 36 & Toot, 2013 & + & + & + & + & + & - & + & + & + & + \\
\hline 37 & Van Hoof, 2009 & + & + & + & + & + & - & - & - & + & + \\
\hline 38 & Vikström , 2005 & + & + & + & + & + & - & + & + & + & + \\
\hline 39 & Wherton, 2008 & + & + & + & + & + & - & + & - & + & + \\
\hline 40 & Yang, 1997 & + & + & + & + & + & - & - & - & + & + \\
\hline
\end{tabular}

Note: The symbol + shows that criteria has been reported and - that was not reported 
Table 6. Key Themes, Subthemes And Contribution of Included Studies

\begin{tabular}{|c|c|}
\hline Key themes and subthemes & Contribution of included studies \\
\hline $\begin{array}{l}\text { 1.1 Home, sweet home } \\
\text { 1.2 Home experience disrupted } \\
\text { 1.3 Home tensions }\end{array}$ & $\begin{array}{l}\text { Aminzadeh, 2010; Askham, 2007; Buri, 2000; Chung, } \\
\text { 1997; Cott, 2013; de la Cuesta, 2005; de Witt, 2009; } \\
\text { Dickson, 2012; Dodds, 1994; Dröes, 2006; Drennan, } \\
\text { 2011;Kinney, 2003; Nochajski, 2013; Nygård, 2008; } \\
\text { Nygård, 2002; Olsen, 1996; Olsson, 2011; Powell, 2010; } \\
\text { Redfrem, 2002; Richter, 1995; Spring, 2009; Sixsmith, } \\
\text { 2007; Taşc1, , 2012; Toot, } 2013\end{array}$ \\
\hline $\begin{array}{l}\text { The ongoing changing } \\
\text { nature of home }\end{array}$ & $\begin{array}{l}\text { Askham, 2007; Buri, 2000; Chung, 2013; Chung, 1997; de } \\
\text { la Cuesta, 2005; Dröes, , 2006; Forbat, 2004; Kinney, 2003; } \\
\text { Lach, 2007; Nygård, 2008; Olsen, 1996; Olsson, 2011; } \\
\text { O’Donnell, 2000; Richter, 1995; Redfern, } 2002 \text {; Smith, } \\
2001\end{array}$ \\
\hline $\begin{array}{l}2.2 \text { Useful home components } \\
2.3 \text { Individualised strategies } \\
2.4 \text { Improvising strategies }\end{array}$ & \\
\hline
\end{tabular}




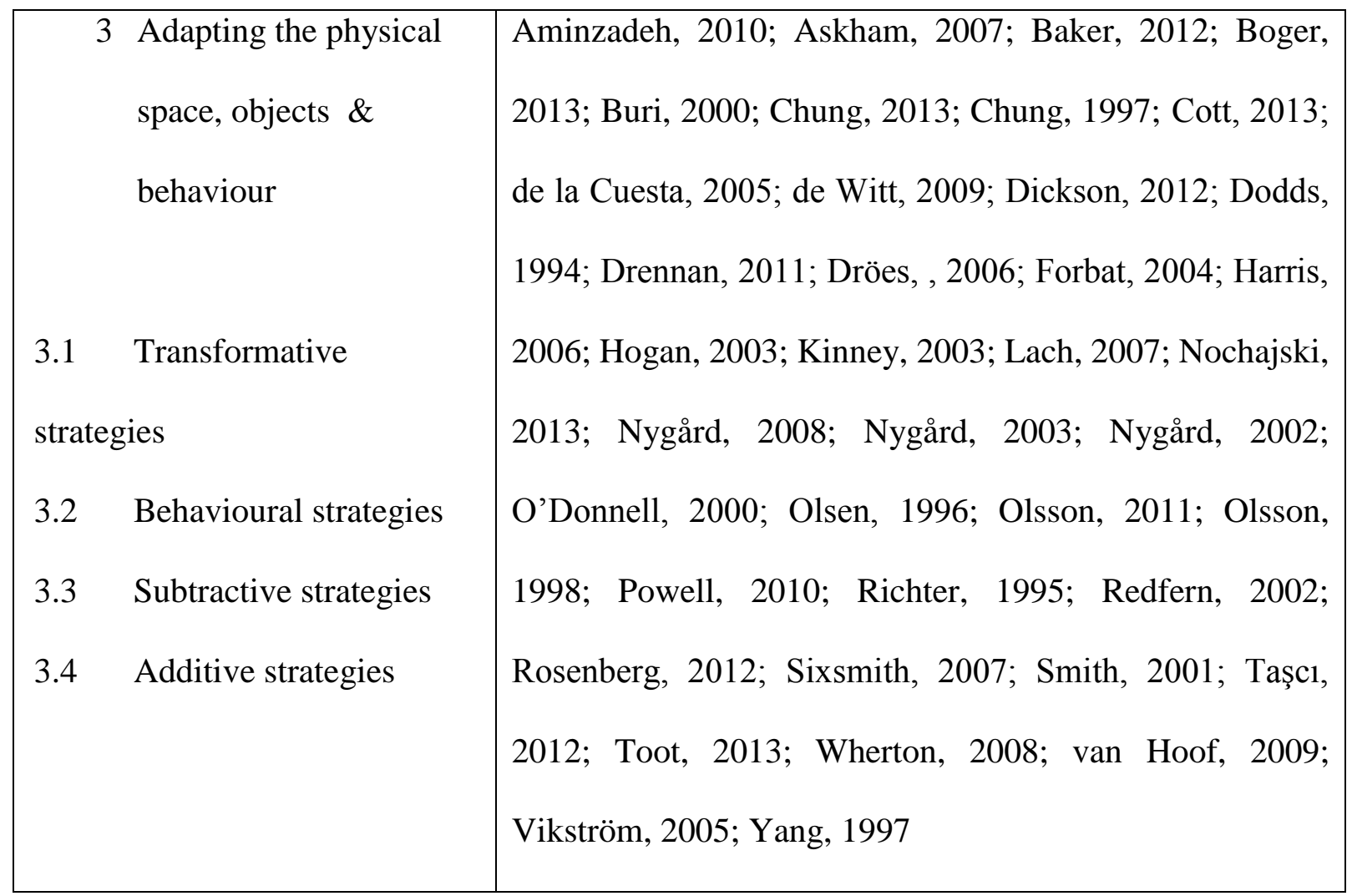


Table 7. Quotations from Included Studies to Support Themes And Subthemes

\begin{tabular}{|c|c|c|c|}
\hline Key themes & Subthemes & \multicolumn{2}{|l|}{ Quotations } \\
\hline \multirow{3}{*}{$\begin{array}{l}\text { 1. Home as a } \\
\text { paradox }\end{array}$} & Home sweet home & $\begin{array}{l}\text { The notion of moving out was like a death sentence for Keisha. 'And when they } \\
\text { mention about me moving out it was just like, you might as well kill me. Cause I, } \\
\text { I wouldn't have stood it (de Witt, 2009). }\end{array}$ & \\
\hline & $\begin{array}{l}\text { Home experience } \\
\text { disrupted }\end{array}$ & $\begin{array}{l}\text { Patients and their families became secluded, as the home was no longer designed } \\
\text { to entertain visitors. When asked if people came to visit, Tulia answered: "No. } \\
\text { Visitors (visitas) are not really coming; few people outside the home come here } \\
\text { to visit" (de la Cuesta, 2005). }\end{array}$ & $\begin{array}{l}\text { "In fact, I do need therapy, too. I mean if there are not two or } \\
\text { three people to care for the patients, you are psychologically } \\
\text { affected. I am a prisoner at home. I go nowhere except the } \\
\text { shopping centre. A prison" (Taşc1, 2012). }\end{array}$ \\
\hline & Home tensions & $\begin{array}{l}\text { Kay further shared her experience with this risk and her disappointment that she } \\
\text { was becoming worse: Sometimes you'd be doing something and I'd forget I got } \\
\text { something on ... as soon as the smoke got there it's been a few times . . . and } \\
\text { that's [smoke detector] come on once or twice .... [my adult children] kept my } \\
\text { oven off .... [there] could be a fire starting you know ... I did enjoy baking but } \\
\text { I don't enjoy baking any more .... . it was kind of disappointing that I was getting } \\
\text { so bad that they would cut that off (de Witt, 2009). }\end{array}$ & $\begin{array}{l}\text { Describing a change of bedrooms, Veronica described the need } \\
\text { to ensure that changes made to the home would preserve the ill } \\
\text { person's well-being. As she recalled: My mother slept in this } \\
\text { room, and we said to her: "Amparo, go to the bedroom to put on } \\
\text { your pyjamas." But she did not go to the room where she was } \\
\text { sleeping, but to the other one where she used to sleep. She sort } \\
\text { of knew: "This is my bedroom." She has slept there all her life, } \\
\text { and when we changed it, she knew that this was really her } \\
\text { bedroom (de la Cuesta, 2005). }\end{array}$ \\
\hline
\end{tabular}




\begin{tabular}{|c|c|c|c|}
\hline \multirow{4}{*}{$\begin{array}{l}\text { 2. There is no } \\
\text { magic formula }\end{array}$} & Ongoing process & $\begin{array}{l}\text { Many carers spoke of the need for structural changes in their homes to enable } \\
\text { their relative to use the toilet as much as possible. This ranged from minor } \\
\text { changes such as fitting grab rails and modifying toilets, to major structural } \\
\text { alterations such as building new ground-level bathrooms (Forbat, 2004). }\end{array}$ & \\
\hline & Personalised strategies & $\begin{array}{l}\text { Although participants supervised their relatives with dementia almost all the } \\
\text { time, they found that accidents still happened. Thus, participants devised some } \\
\text { interventions to prevent carers from any potential accidents. One participant hung } \\
\text { a bell on the door to prevent his wife with dementia from wandering out without } \\
\text { his notice (Chung, 1997). }\end{array}$ & \\
\hline & Home improvisations & $\begin{array}{l}\text { Relatives also invented their own nontechnical solutions to increase security for } \\
\text { the person with dementia and for themselves. They hoped that these solutions } \\
\text { would minimize or completely prevent the risk of the person with dementia } \\
\text { leaving home on his/her own. I come up with my own alarms, a stool or bench in } \\
\text { front of the door, a bunch of bells on a band that falls to the floor when someone } \\
\text { uses the door handle (Relative 3) (Olsson, 2011). }\end{array}$ & $\begin{array}{l}\text { "One has to have many clues with them [relative with dementia]; } \\
\text { one has to invent many things" (de la Cuesta, 2005). }\end{array}$ \\
\hline & $\begin{array}{l}\text { Important home } \\
\text { components }\end{array}$ & $\begin{array}{l}\text { "She does not get lost anymore, not in this moment, but I would not move out } \\
\text { with her because in an apartment or in a small house it would be very difficult; it } \\
\text { has to be big spaces, a pretty big home [like the one in which they are living] and } \\
\text { I think this [having space] has served for her to last so long" (de la Cuesta, 2005). }\end{array}$ & $\begin{array}{l}\text { As one wife carer said, 'You go upstairs to do a job and you're } \\
\text { not up there two minutes when he's calling and wanting me. So } \\
\text { down I come. I go up-and-down those stairs so many times } \\
\text { during the day' (Askham, 2007). }\end{array}$ \\
\hline
\end{tabular}




\begin{tabular}{|c|c|c|c|}
\hline \multirow{4}{*}{$\begin{array}{l}\text { 3. Adapting the } \\
\text { physical space and } \\
\text { objects at ome }\end{array}$} & $\begin{array}{l}\text { Transformative } \\
\text { strategies }\end{array}$ & $\begin{array}{l}\text { The caregiver showed signs of adapting the physical space and objects in the } \\
\text { performance area through providing space, removing irrelevant objects, and } \\
\text { placing objects relevant to the activity forward (Vikström, 2005). }\end{array}$ & $\begin{array}{l}\text { Adela and her husband moved their bedroom to be close to her } \\
\text { mother so they could hear her at night if she needed help (de la } \\
\text { Cuesta, 2005). }\end{array}$ \\
\hline & Behavioural strategies & $\begin{array}{l}\text { Following the same habitual pattern and sequences of activities were commonly } \\
\text { spoken of as a powerful strategy. For one participant, the daily routines were } \\
\text { even described as "making rituals" (Nygård, 2002). }\end{array}$ & $\begin{array}{l}\text { As long as she is in familiar surroundings, she does rather well } \\
\text { in finding her way around. Even at night, she can still find her } \\
\text { way to the toilet or bathroom and gets into bed again. But once } \\
\text { she gets into a strange environment, then that's a totally different } \\
\text { matter (Study 2: Caregiver) (Wherton, 2008). }\end{array}$ \\
\hline & Subtractive & $\begin{array}{l}\text { Several caregivers removed objects that their loved ones could trip over (eg, } \\
\text { throw rugs, ottomans, magazine racks) or break (eg, knickknacks, ashtrays, } \\
\text { display plates) to create safe wandering paths (Olsen, 1996). }\end{array}$ & $\begin{array}{l}\text { He kept on his winter coat for long, as well as his gloves. I put } \\
\text { away the winter coat for a while, in order for him not to see it } \\
\text { anymore so that he won't ask for it. There is only one coat on the } \\
\text { coat rack, else it is too confusing (van Hoof, 2009). }\end{array}$ \\
\hline & Additive strategies & $\begin{array}{l}\text { 'I have to motivate him to do something... He always loved music, but there was } \\
\text { one - It is the Ink Spots. If I wanted him out of bed, wanted him to do anything, } \\
\text { to go for a walk, the Ink Spots... when he heard the Ink Spots it was amazing and } \\
\text { suddenly his face was calmer, I mean, ... something clicked and then he would } \\
\text { get up and then I could dress him and we would have breakfast, and then he was } \\
\text { happy. And if you had him in that mood, that happy, then you can suggest, we } \\
\text { went for a walk - that music - it was just the motivator' (Chung, 2013). }\end{array}$ & $\begin{array}{l}\text { Family carers and staff highlighted the value of assistive } \\
\text { technology such as gas detectors, alerts/pagers and movement } \\
\text { detectors. One carer said, 'If you are worried about somebody } \\
\text { getting out of bed, or getting out of a chair, like I was, they are } \\
\text { absolutely brilliant. It actually gave me a bit more freedom as } \\
\text { well (Toot, 2013). }\end{array}$ \\
\hline
\end{tabular}


